\title{
HACIA UNA SISTEMATIZACIÓN DEL MARCO POLÍTICO Y SOCIO-ECONÓMICO DE GADIR DURANTE DURANTE LA ETAPA PÚNICA (SIGLOS VI-V A. N. E.)
}

\section{TOWARDS A SYSTEMATISATION OF THE POLITICAL AND SOCIO-ECONOMICAL ORGANIZATION OF GADIR DURING THE PUNIC PERIOD (VI-V B.C.)}

\author{
por \\ ÁNGEL MUÑOZ VICENTE \\ GREGORIO DE FRUTOS REYES
}

RESUMEN Este trabajo tiene por objetivo marcar unas pautas generales para la reconstrucción de los modos de organización política, económica y social de la polis gadeirita. Para ello nos basamos en la conjugación de las aportaciones de los recientes sondeos geo-arqueológicos con los restos arqueológicos y los datos suministrados por los textos.

\begin{abstract}
The ain of this work is to assign general standards in order to reconstruct the ways of political, economic and social organization of "la polis gadeirita". For this reason, we have based on the union of the contributions in the recent geo-archaeological soundings, the archaeological rests and the information provided by the written texts.
\end{abstract}

Palabras claves Gadir, Cartago, Circunscripción Púnica Gaditana, Círculo Púnico Centro Mediterráneo, Puertos de Comercio, Industrias de salazones y salsas de pescado gaditanas.

Key words Gadir, Carthage, Punic Circumscription Gaditana, Punic Cicle Mediterraneam Center, Ports of trade, Industry of SALT metas and sauces of Gaditana fish.

\section{INTRODUCCIÓN}

La práctica arqueológica en las últimas décadas en la Bahía de Cádiz, se ha caracterizado en líneas generales por su desarrollo paralelo a la dinámica urbanística, atendiendo casi con exclusividad a documentar y proteger los elementos conformadores de nuestro pasado puestos en peligro por cualquier tipo 
de actividad con afección al subsuelo. Muy escasos han sido los proyectos realizados desde planteamientos sistemáticos de investigación y siempre para la protohistoria, circunscritos al estudio de yacimientos concretos, sin tener en cuenta su contexto territorial y paleotopográfico.

En estas circunstancias resulta evidente que las numerosas investigaciones de carácter aislado que se realizan bajo la dinámica de urgencia o prevención en nuestras ciudades vienen aportando datos del mayor interés, aunque con un tratamiento dispar en métodos y sistemas de registro y que sólo trascienden al mundo científico de una manera muy parcial o sectorizada. Esta problemática sólo puede ser abordada desde estudios de conjunto que agrupen la amplia documentación generada por estas intervenciones, mediante su canalización a través de proyectos generales de investigación integrados por equipos interdiciplinares.

En este panorama intentamos hace algunos años esbozar un primer acercamiento al estudio de la ciudad de Cádiz durante la protohistoria desde un análisis territorial y cuya pretensión no fue otra que ofrecer un esquema secuencial del poblamiento, basado en esa información dispersa fruto de las numerosas excavaciones practicadas (Muñoz Vicente 1995-96: 77-105). Con posterioridad, el proyecto geoarqueológico realizado en el casco antiguo de Cádiz en el año 2001 bajo la dirección de los profesores Arteaga y Schulz, que supuso la continuación de los trabajos desarrollados en el saco interior de la Bahía bajo la denominación de proyecto Antípolis (Arteaga et alii 2001), ofrecieron las primeras bases científicas desde donde abordar la revisión de todos estos datos al mismo tiempo que establecer una nueva lectura de los textos de los autores antiguos.

El presente artículo se enmarca en esta nueva línea de investigación surgida a raíz de los mencionados estudios y cuyo primer debate y puesta en común se llevó a cabo en los XIX Encuentros de Historia y Arqueología de San Fernando, celebrados en el mes de noviembre de 2003. Desde entonces venimos desarrollando determinados aspectos sobre estas cuestiones, ampliando la documentación presentada y acotándola en periodos más cortos, pero siempre dentro de esa línea general de investigación. En esta ocasión abordaremos el estudio de Gadir y su territorio a partir de las circunstancias y avatares históricos que tuvieron lugar desde la segunda mitad del siglo VI a.n.e.

\section{LOS REGISTROS ARQUEOLÓGICOS}

Desde época fenicia arcaica en las islas de Cádiz se configura un esquema de poblamiento que prácticamente no va a sufrir transformación durante la protohistoria.

Los distintos registros arqueológicos que ha deparado la ciudad de Cádiz nos informan de una estructuración de la población en torno al puerto interior de la actual plaza de la Catedral, puesto de manifiesto en los recientes sondeos geoarqueológicos mencionados (Arteaga et alii 2001). En un principio se ocuparían las zonas inmediatas al altozano de la Torre Tavira (niveles inferiores de la calle San Miguel, Ancha y Cánovas del Castillo, éstas dos últimas monofásicas de finales del siglo IX-principios del siglo VIII a.n.e.), para en fases sucesivas ir ampliando la superficie habitada hacia el exterior, ocupando incluso lugares de la isla de enfrente (la mayor o Cotinusa), pero siempre en las cercanías de esa zona portuaria (calles Concepción Arenal y Paraguay).

A partir de finales del siglo VII/principios del siglo VI a.n.e., se observa un paulatino abandono de los sectores de la calle San Miguel y Concepción Arenal, no volviéndose a ocupar hasta momentos coincidentes con la presencia romana en Gadir (finales del siglo III a.n.e.) y sobre todo hasta la estructuración sufrida en el siglo I a.n.e. con el nuevo planteamiento urbanístico de la familia de los Balbo.

Estos hiatos de uso no son de extrañar en áreas urbanas tan amplias, pues por ejemplo en el Castillo de Doña Blanca, el denominado por su excavadores "barrio fenicio" se abandona a finales 
del siglo VIII a.n.e., convirtiéndose en una zona de basurero hasta los siglos V-III a.n.e., cuando se construyen nuevas murallas (Ruiz y Pérez 1995: 62).

Si en el siglo VI a.n.e. el sector del barrio de Santa María de Cádiz presenta una escasa o casi nula presencia fenicia, la excavación de la calle Paraguay, en el barrio de la Viña, sí aporta datos suficientes al respecto. Así las formas cerámicas más características son las ánforas A1 de nuestra tipología (Muñoz Vicente 1987: 472), encuadrables en el tipo 10.1.2.1 de J. Ramón (1995: 230-231). Las lucernas de dos picos continúan, documentándose algunas con engobe blanco sobre el que se extiende una capa de pintura rojo brillante. A principios de este siglo aparecen los cuencos semiesféricos con bordes engrosados al interior, recubiertos por dentro con engobe rojo poco consistente. La misma forma de cuenco se documenta en la variedad de "cerámica gris", con tonalidades superficiales de color gris claro uniforme sobre pasta gris-verdosa. Igualmente están presentes los cuencos con carenas y bordes salientes sin decoración alguna, y los platos de engobe rojo de borde ancho (Muñoz Vicente 1995-96: 82).

Del área de la necrópolis gaditana conocemos una estructura de pozo de forma cilíndrica inédita excavada por nosotros en 1983 en la playa de Santa María del Mar, en la zona de Extramuros. Dicho pozo, al que denominamos SMM/83/P1, presentó ocho niveles de depósito que oscilaban entre los $0,11 \mathrm{mts}$ del nivel 2 y los $2,13 \mathrm{mts}$ del nivel 7, teniendo una potencia total de 7,10 mts. y un diámetro medio de 1,30 mts. Por el material recogido y disposición de los niveles podemos afirmar que la estructura localizada perteneció a un enterramiento del segundo cuarto del siglo VI a.n.e., siendo violentado a finales del mismo siglo y pasando desde entonces a convertirse en vertedero. En este sentido el enterramiento se situaría en los niveles 7 y 8 y se trataría de una incineración en urna tipo Cruz del Negro evolucionada. Entre los materiales de estos niveles del enterramiento se localizaron varios fragmentos de ánforas A1b (=T.10.1.2.1.), uno de una A3 (=T.11.2.1.1), un fragmento de lucerna de dos picos, algunos fragmentos de platos de engobe rojo con bordes anchos, cuencos carenados y dos fragmentos de trípodes (Muñoz 1995-96, 81). De los niveles superiores, cuando el pozo se convierte en vertedero, conocemos una boca de un ánfora $\mathrm{A} 4 \mathrm{a}(=\mathrm{T} .11 .2 .1 .3)$, así como otros fragmentos de tipos ibéricos.

En esta misma zona de Santa María del Mar, durante 1991, se realizaron una serie de obras de acondicionamiento del talud de la playa, que permitió excavar una serie de pozos, uno de los cuales, el denominado $n^{\circ} 3$, suministró un importante depósito de materiales muy homogéneos que nos sitúan en los momentos finales del siglo V/principios del siglo IV a.n.e. Junto a bases de skyphoi de barniz negro áticas de la forma Lamboglia 43, cuencos áticos, fragmentos de lucernas de dos picos y platos con engobe rojo, encontramos varios fragmentos de ánforas corintias $\mathrm{B}$, varios bordes de ánforas ibéricas originarias de la costa catalana y siete fragmentos de borde y parte de los cuerpos y asas de ánforas ebusitanas del tipo 8.1.1.1. de J. Ramon, fechado entre el 400/390 y el 300 a.n.e. (Ramon 1995, 221-222).

Igualmente de este sector de la playa de Santa María del Mar conocemos una serie de materiales anfóricos entregados en el Museo de Cádiz a principios de los años ochenta, entre los que hemos podido identificar un borde de A1b (=T.10.1.2.1), uno del A4a (=T. 11.2.1.3) y un fragmento del borde, cuerpo $\mathrm{y}$ asa de un ánfora $\mathrm{A} 6$, con decoración pintada a bandas horizontales y verticales y trazos en zig-zag en tonalidades rojizas y negras similares a los fragmentos pintados localizados en el alfar del sector III de Camposoto.

Posteriormente, en unas excavaciones de urgencia en un solar de la calle Tolosa Latour, se ha excavado un enterramiento en fosa en una urna de la misma tipología, quizás de cronología algo más antigua de principios del siglo VI a.n.e. (Muñoz Vicente 1998: 145).

De la primera mitad de este siglo conocemos además un buen número de sepulturas que se circunscriben a un sector de Extramuros (Perdigones, Muñoz y Pisano 1990: 11-31; Muñoz Vicente 1998: 
138-149), y cuyos límites, en el actual estado de la investigación lo constituyen por el sur los enterramientos de la plaza de Asdrúbal (excavaciones de 1983-84), por el norte las proximidades de la Puertas de Tierra (excavaciones en la c/ Juan R. Jiménez), por el este los ejemplos de la calle Tolosa Latour (excavaciones de 1987/88) y por el oeste los enterramientos de la Avda. de Andalucía 32-42 (excavaciones de 1990) y los de la Avda. Fernández Ladreda (excavaciones de 1989). No obstante en estos últimos años se han localizado enterramientos similares en los terrenos de la Segunda Aguada, ubicada muy al sur de la plaza de Asdrúbal en el sector interior de la bahía.

La tipología responde a incineraciones "in situ" en fosas dobles similares a las localizadas en Ibiza y denominadas fosas con canal (Lámina 3) o simples, excavadas en la arcilla rojiza o roca ostionera. Los ajuares lo constituyen objetos de adorno personal (pendientes, anillos, collares, medallones etc) (Lámina 2) y cerámicas tales como platos con engobe rojo con bordes entre 5,1 y 6,7 cms. de anchura, lucernas de dos picos con engobe rojo, cuencos carenados, ampollas y ollas de cerámica tosca (Lámina 1). Además conocemos dos fragmentos de copas griegas arcaicas localizadas en la tumba $n^{0} 53$ de la excavación de la plaza de Asdrúbal de 1984. Directamente relacionado con estos enterramientos es el fragmento de ánfora de Quíos localizado en la misma excavación en un nivel de la $1^{\mathrm{a}}$ mitad del siglo VI a.n.e., y que corresponde a parte del borde, cuello y asa. El fragmento pertenece al tipo de ánfora con pasta marrón con desgrasante de tipo arenoso con inclusiones de mica y engobe blanco muy consistente sobre el que se aplica una decoración basada en pintura de color rojizo que ocupa la totalidad del borde, una línea en el cuello y restos en el asa (Muñoz Vicente: 1987: 477; Id. 1995-96: fig. 16, $\mathrm{n}^{\circ} 1$ ) (Lámina $11 \mathrm{n}^{\circ}$ 1).

Sin embargo a partir del siglo $\mathrm{V}$ a.n.e. son escasas las huellas materiales documentadas en las posibles zonas urbanas comentadas para los siglos anteriores. Sólo se conocen algunos fragmentos de ánforas del tipo A4a (=T.11.2.1.3), del siglo V a.n.e. y derivadas A4c/d (=T.12.1.1.1) y A4e $(=\mathrm{T} .12 .1 .2 .1)$ de los siglos IV-III a.n.e.

Además están presentes por lo que se refiere a la calle Paraguay los cuencos de cerámica gris con bordes engrosados al interior, los platos carenados con borde estrecho horizontal con engobe blanco sobre la parte interior que se cubre con pintura roja fechados en el siglo $\mathrm{V}$ a.n.e. y los platos pequeños con borde saliente horizontal recubierto con engobe rojo, de finales del siglo $\mathrm{V}$ / principios del siglo IV a.n.e. (Muñoz Vicente 1995-96: 83)

Paradójicamente, las escasas o nulas noticias sobre restos urbanos, se corresponden sin embargo con unos momentos muy bien conocidos tanto a nivel de necrópolis como de industrias, principalmente de salazones. Los niveles de estas factorías, adquieren desde principios del siglo $\mathrm{V}$ a.n.e. gran importancia. De ellas conocemos dos grandes áreas: una excavada entre 1983-84 en la plaza de Asdrúbal y otra excavada en 1986 en la Avda. de Andalucía e/a c/ Ciudad de Santander (Muñoz, Frutos y Berriatúa 1988: 489-490).

No obstante la revisión de los materiales de los primeros trabajos realizados en 1984 en la primera mencionada, ha proporcionado datos del mayor interés al documentarse en el nivel de base de la factoría (Estrato IIIA) fragmentos de ánforas A4a (=T.11.2.1.3.) con bordes de una de las variantes del sector 3 de Campososto, que permiten establecer el inicio de las actividades al menos en el último cuarto del siglo VI a.C. (Muñoz y Frutos 2004: 135).

De los primeros momentos de su actividad no conocemos estructuras pero sí escombreras o fosas con materiales de desecho (Lámina 10). En ellas se han localizado asociadas con restos de atunes ánforas de tipo A4a (=T.11.2.1.3), los mismos materiales que encontramos en el otro extremo del Mediterráneo en Corinto, en el denominado "edifico de las ánforas púnicas" (Williams II 1978: 15-20). Queda pues bastante claro que estas ánforas transportaban productos derivados de la pesca elaborados en el área del Estrecho de Gibraltar. Además de éstas ánforas se localizaron platos con engobe rojo de borde ancho y pequeño diámetro, cuencos y otros vasos de cerámica común de diversa tipología, así como cerámicas griegas de la clase de Saint-Valentín tipo skyphoi con guirnalda de hoja de mirto, lucernas y 
copas Cástulo y ánforas corintias A’ y B (Lámina $11 \mathrm{n}^{\circ} 2$ a 6). Junto a las cerámicas, útiles para la pesca (anzuelos, plomadas, agujas de coser redes etc.), así como abundante material malacológico y vértebras de espinas de atunes (Muñoz Vicente 1995-96: 82-83).

Desde los inicios del siglo IV a.n.e. el porcentaje de materiales desciende, lo que debe indicarnos un decaimiento de la actividad, circunstancia que continuó hasta el último tercio del siglo III a.n.e., cuando asistimos a una fuerte reactivación de las actividades. A este periodo corresponden varios suelos de piedras y cerámicas destinados a la limpieza y almacenamiento del pescado. Por lo que se refiere a los materiales, los tipos anfóricos más representados son los A4c/d (=T.12.1.1.1), A4e $(=\mathrm{T} .12 .1 .2 .1), \mathrm{A} 4 \mathrm{f}$ (=T.12.1.1.2), A5 (=T.8.2.1.1), E2a (=T.9.1.1.1), D2 (=T.5.2.3.1) y E3 (=T.4.2.2.5).

En un sector próximo a estas factorías, en la Av. de Portugal, se localizaron los restos de una pileta asociada a un ánfora E1 (=T.8.1.1.2) (Lámina 12).

En El Puerto de Santa María conocemos una gran zona industrial dedicada a la elaboración de productos derivados de la pesca, integrada por más de una veintena de pequeños enclaves situados en la franja costera entre los ríos Guadalete y Salado. Los dos únicos excavados hasta hoy día, el de Las Redes en 1980 (Muñoz, Frutos y Berriatúa 1988; Frutos y Muñoz 1996; Muñoz y Frutos 2004) y el de Pinar Hondo (Puerto 19) en 1996 (Gutiérrez 2004: 237-262), nos permiten conocer sus características y su estructuración interna. Se trata de pequeños recintos de planta casi cuadrada o rectangular, de no más de 120 metros cuadrados, con muros con cimientos de mampuestos de piedra sin llegar a constituir un espacio cerrado. Se cubrirían con una estructura vegetal apoyada en postes de los que quedaron testimonios en el nivel de ocupación de la factoría de Pinar Hondo. La distribución interna en el caso de Las Redes (la mejor conservada), constaba de una sala de entrada y cuatro dependencias dedicadas respectivamente a la transformación industrial del pescado, limpieza de los productos pesqueros, almacenamiento de utensilios y área de producción con dos piletas para la maceración del pescado.

Al periodo que analizamos corresponden las fases I y II de las Redes y II y III de Pinar Hondo, que centran el auge de la factoría en el siglo $\mathrm{V}$ y buena parte del siglo siguiente, documentándose en éste último una reducción de la extensión de las factorías que anuncia su decadencia. Los materiales en líneas generales responden a los tipos de ánforas mencionados para las factorías gaditanas. De este amplio complejo industrial de salazones portuense, conocemos además una serie de fragmentos de ánforas procedentes de una prospección con sondeos estratigráficos llevados a cabo por J. A. Ruiz Gil en 1986 en las denominadas factorías $\mathrm{n}^{\circ} 14$ y 16 . La publicación donde se dan a conocer estos materiales no especifica la localización estratigráfica de los mismos ni su contexto, analizándose únicamente por los paralelos en el Cerro Macareno y La Tiñosa (Ruiz Gil 1987: 104, fig. 1). Entre los fragmentos publicados podemos distinguir en el $\mathrm{n}^{\mathrm{o}} 14$ varios bordes de A4a y más concretamente un ejemplo de T. 11.2.1.5, tres de T. 11.2.1.3 y uno de una posible T.11.2.1.1 y otro de una T.11.2.1.6. De la factoría $\mathrm{n}^{\circ} 16$ los materiales publicados se limitan a varios ejemplares de bordes turdetanos y a un fragmento de una A4a $(=$ T.11.2.1.3) y otro de una A5 (=T.8.2.1.1).

Si la investigación arqueológica en la ciudad de Cádiz para los siglos V y IV a.n.e. no ha suministrado prácticamente testimomios urbanos, en el cercano yacimiento de Doña Blanca durante los primeros decenios del siglo $\mathrm{V}$ a.n.e presenta una nueva estructuración interna y se fortifica con nuevos sistemas de defensa. Las cerámicas evolucionan hacia formas y tipos turdetanos, aunque manteniendo las tradiciones orientalizantes (Ruiz y Pérez 1995: 72). No obstante las campañas de excavaciones realizadas en este poblado tampoco han ofrecido datos abundantes para esta centuria. Mayor información disponemos para los siglos IV y III a.n.e a través de los trabajos realizados durante 1982-83 en la esquina sudeste del poblado y durante 1991 en el asentamiento de Las Cumbres, ubicado en parte más alta de la Sierra de San Cristóbal (Ruiz y Pérez 1995: 105-106). Para estos momentos la configuración urbana se articulaba en calles e ínsulas y zonas abiertas o plazas.

ISSN: 1133-4525 ISSN-e: 2255-3924

SPAL 14 (2005)

http://dx.doi.org/10.12795/spal.2005.i14.05 
En el yacimiento de Las Cumbres, las estructuras excavadas apuntan a un carácter industrial relacionado con la producción de vino. Se han excavado dos lagares compuestos de dos piletas superiores donde se pisaba la uva, que conectan mediante unos canalillos con otra inferior donde se recogía el zumo. Otro lagar de las mismas características se ha documentado en el sector sudeste de Doña Blanca.

Por lo que se refiere a la industria alfarera el territorio de San Fernando para el periodo que analizamos, está proporcionando datos del mayor interés. El complejo industrial de Camposoto, inició sus actividades en el último cuarto del siglo VI a.n.e., aunque ciertos materiales podrían indicarnos su fundación algunas décadas antes (Lámina 8).

El complejo alfarero, actualmente en estudio, se configura en dos ámbitos separados, presididos respectivamente por un horno de gran tamaño y una serie de estructuras menores.

El primer grupo de hornos comprende un número total de cinco.

El horno principal $\left(\mathrm{n}^{\mathrm{o}} 1\right)$ tiene planta circular y conserva parte de la cámara de cocción. El suelo de ésta presenta dieciséis toberas o chimeneas, 11 de ellas dispuestas circularmente siguiendo el perímetro de la parrilla y otras cinco centrales.

El corredor de acceso a la cámara de combustión es de forma alargada, del cual sólo se conserva el suelo y parte del arranque de la pared, compuesta por un muro de mampuestos de piedras. Junto a la entrada había una especie de cimentación semicircular de piedras de diferentes tamaños que posiblemente formaron parte del frontal del horno.

La cámara inferior tiene planta circular de tipo "omega", con un pilar central ovalado con un contrafuerte rectangular en la parte posterior, que le confiere un aspecto de muro longitudinal como en los hornos de Motia, Desde la pared al pilar arrancan los arcos que sustentaban la parrilla.

Se ha podido constatar que este horno fue recompuesto en su pared interna de la cámara de combustión. También se ha podido ver el sistema constructivo consistente en una fosa excavada en la arcilla donde disponían adobes rectangulares y sobre estos colocaba el horno propiamente dicho.

El otro horno de este grupo (el $\left.\mathrm{n}^{\circ} 5\right)$ se encontraba a cuatro metros del primero. Presenta una parrilla con seis chimeneas. El lugar de la entrada está seccionado por una zanja rellena con material cerámico, defectos de cocción, escoria y restos óseos de animales y malacofauna. Estaba totalmente colmatado en su interior y no tenía entrada ni pilar que sustentase la parrilla. También estaba excavado en el terreno natural.

El segundo grupo lo componen los hornos número 2 y 3 .

El horno número 2 apareció bajo una enorme escombrera de material cerámico púnico. Dicha estructura había sufrido numerosas reconstrucciones y estuvo en producción durante un largo período de tiempo.

En su fase más antigua se utilizaron para su construcción placas de adobes rectangulares de unos 47 $\mathrm{cm}$ por $30 \mathrm{~cm}$ aproximadamente sobre la fosa excavada en la arcilla y reforzada con pequeños ladrillos de adobe. Dicho horno tiene una entrada flanqueada por una fachada a modo de sendas columnas de mampuestos de piedras de diferentes tamaños usadas posiblemente como elemento constructivo para reforzar el horno, disposición muy similar al horno 1 de Motia o al D de Sarepta.

En las citadas placas, se puede apreciar un nivel donde se pudo constatar un resto de la parrilla muy diminuto, conservándose parte de la cámara de cocción.

El pilar central tiene forma elíptica, al igual que la planta, encuadrable en el tipo "omega", con un contrafuerte hasta la pared. Posiblemente ese sea el mismo pilar central de la segunda etapa del horno, que fue reconstruido con nuevas paredes al serle inservible la primera pared.

Tras estos dos períodos de uso el horno sufre un período de abandono e inactividad en el que se rellena con varios niveles de cerámica que se dejan ver en sus paredes y entre su segunda y tercera reconstrucción a 1,20 metros del suelo más antiguo. 
Sobre este relleno se vuelve a reconstruir el horno más moderno reduciéndose entonces mucho sus medidas pues llega a tener 4,40 en su lado mayor y 2,10 en el menor. De esta fase también conserva su pilar central de 2,10 x 1 metro de ancho y se rehace la entrada dándole una elevada altura con cuatro escalones que aparecieron quemados. No conserva parrilla ni cámara de cocción. Tras su abandono se colmata con un relleno cerámico y, sobre el mismo, posteriormente se abren una serie de fosas de enterramientos, en concreto tres, que cortan las paredes del horno y que podemos fechar durante el siglo III a.n.e.

El horno número 3 conserva la cámara de combustión, con parte del pilar central, parte de la parrilla y parte de la cámara de cocción. Su planta tiene forma elíptica

La cámara de cocción presenta una altura máxima de $1 \mathrm{~m}$ en su lado opuesto a la entrada. Dicha cámara estaba totalmente colmatada con un total de cuatro niveles diferenciables según el color de la arena y su contenido. Entre dicho material se hallan muchos restos de asas de ánforas y sobre todo numeroso material pintado, (jarras y grandes platos) y fragmentos de platos de barniz rojo, además de un nivel con cerámicas de imitación de copas áticas de barniz negro, restos de malacofauna y carbones.

La parrilla sólo se conserva en parte. La cámara de combustión estaba igualmente rellena de material cerámico del mismo tipo al anteriormente citado: restos de ánforas pintadas, platos de engobe rojo, etc. El pilar central, conservado también en parte, tiene forma elíptica, no presentando prolongación hasta la pared trasera del horno

Enfrente a los dos hornos existía un espacio de trabajo donde se documentaron ánforas en doce niveles diferentes, que llegaron a tener una potencia de 3 metros. Las ánforas estaban colocadas de una manera más o menos ordenada, bien tumbadas, bien boca abajo. Todas eran ánforas del tipo A4a, pero con leves variantes en su boca. Estaban completas y se contabilizaron un total de 54 ejemplares. Gran parte de ellas estaban rellenas o formaban parte de un relleno a su alrededor de restos de malacofauna (Lámina 9). Junto a las ánforas también aparecieron numerosos restos de platos de barniz rojo, restos óseos, terracotas y moldes de terracotas.

En consecuencia, y a modo de una primera interpretación de los resultados de las excavaciones, podemos establecer el inicio de la producción en el último cuarto del siglo VI a.n.e. continuando hasta al menos la segunda mitad del siglo siguiente. Los recipientes elaborados corresponden masivamente a ánforas $\mathrm{A} 4 \mathrm{a}$ (= T.11.2.1.3.), jarros con un asa decorados y algunas cerámicas de pequeño tamaño como tapaderas, platos sin tratamiento de superficie o con engobe rojo y borde ancho, así como quemadores de perfumes y copas que imitan formas griegas de barniz negro

Otro complejo alfarero documentado en el territorio de San Fernando es el de Pery Junquera. Estaba situado al oeste de Torre Alta en las proximidades de la antigua línea de costa. Los trabajos realizados bajo la dirección de B. González durante 1997 sacaron a la luz un complejo industrial alfarero y conservero datado entre finales del siglo III a.n.e. y la primera mitad del siglo I a.n.e., si bien se han documentado materiales anfóricos que abarcan los siglos VI y V a.n.e.. A la fase púnica se asignan un total de once estructuras de hornos de diferentes tamaños y cronologías, los restos de una posible factoría de salazones y un edificio del que desconocemos su funcionalidad. Los materiales anfóricos más antiguos responden a la forma A4a $(=\mathrm{T} \cdot 11.2 .1 .3$.$) . Con cronologías más tardías encontramos los tipos A4f$ $(=\mathrm{T} .12 .1 .1 .2),. \mathrm{A} 5$ (=T.8.2.1.1.), E3 (=T.4.2.2.5.), E1 (=T.8.1.1.2.), E2 (=T.9.1.1.1.) y F1 (=T.7.4.3.3.) (González Toraya et alii 2001).

Los últimos trabajos realizados en la carretera de Camposoto han permitido identificar un nuevo taller alfarero en la zona conocida como Villa Maruja (Bernal et alii 2003, 50-101). De este yacimiento conocemos varias escombreras de materiales que nos sitúan en líneas generales durante los siglos $\mathrm{V}$ y IV a.n.e. A pleno siglo $\mathrm{V}$ corresponden ánforas $\mathrm{A} 4 \mathrm{a}$ (=T.11.2.1.3) y jonio-masaliotas de imitación. De finales de esta centuria e inicios de la siguiente corresponden los tipos $\mathrm{A} 4 \mathrm{a}(=\mathrm{T}$. 11.2.1.4 y 11.2.1.5) y adentrándose en el siglo IV los A4c (=T.21.1.1.1) y A5 (=T.8.2.1.1).

ISSN: 1133-4525 ISSN-e: 2255-3924

SPAL 14 (2005)

http://dx.doi.org/10.12795/spal.2005.i14.05 
Otra actividad industrial desconocida a nivel de publicaciones, presente en la ciudad de Cádiz es la fundición de metales. El ejemplo más antiguo procede de unas excavaciones de urgencia del Museo de Cádiz en 1983 en el pozo de la playa de Santa María del Mar (SMM/83/P1) comentado en el apartado de la necrópolis, donde en niveles de rellenos se localizaron una serie de fragmentos cerámicos de paredes muy gruesas, decorados en el exterior con impresiones digitales, cerámicas muy similares a las localizadas en los niveles inferiores de la Colina de Byrsa en Túnez, que corresponden a campanas de hornos de fundición (Lancel 1982: 249-255). Junto a estas cerámicas se hallaron igualmente algunas escorias y fragmentos de hierro (Lámina 14). Estos hornos constan de una fosa semiesférica excavada en el suelo en la que se coloca un recipiente cerámico de la misma forma, que sobresale del suelo unos centímetros para permitir el acoplamiento del cuerpo e instalación de las toberas. Estos fragmentos proceden del nivel 6, es decir de la primera mitad del siglo $\mathrm{V}$ a.n.e., fecha que nos indica su depósito como materiales desechables. Pese a estas evidencias de estructuras funerarias y posterior uso como vertedero, recientemente se viene insistiendo en el carácter ritual de este pozo, así como en el de otros mucho localizados en la necrópolis gaditana (Niveau 2001).

A estos siglos pertenecen igualmente los vestigios de trabajos de cantería documentados en las excavaciones de urgencia de la plaza de San Antonio, llevada a cabo por la Delegación Provincial de Cultura. Esta cantera representa, hasta hoy día, el único ejemplo arqueológicamente documentado de trabajos de ésta índole en época protohistórica en la ciudad de Cádiz. Los datos de las excavaciones nos muestran una fecha de apertura de al menos el siglo V a.n.e. (Lámina 13).

De excepcional importancia es el hallazgo de un grupo de bustos de terracotas de gran tamaño localizados en 1990 en las excavaciones de la Delegación Provincial de Cultura en un solar de la calle J. Ramón Jiménez e/a Avda. de Andalucía. Su contexto y disposición espacial, así como sus propias características en las que se aprecian agrietamientos y deficiente cocción, nos indican que nos encontramos ante un vertedero de un taller de terracotas de carácter ritual de los siglos V-IV a.n.e. (Álvarez y Corzo 1993-94: 67-82). Su iconología sugiere representaciones de una deidad femenina, que en el caso de la que porta un ciervo habría que relacionar con el culto a Astarté. El destino de estas terracotas elaboradas en Gadir debió encaminarse al uso votivo en santuarios (Lámina 16) (Ferrer Albelda 1995-96).

Por lo que se refiere a la necrópolis, a partir de la segunda mitad del siglo VI a.n.e. y sobre todo en los años finales de esa centuria, se produce un cambio radical en el ritual funerario. Las incineraciones son sustituidas masivamente por las inhumaciones. Esta circunstancia responde a importantes cambios de índole política y económica, ocurridos en el Mediterráneo Occidental tras la desintegración del modelo arcaico colonial fenicio y en el que Cartago debió participar activamente. La necrópolis gaditana a partir de estos momentos no es sino el reflejo de la nueva situación, que se ve plasmada en la adopción generalizada de nuevos rituales y costumbres funerarias.

Estos cambios debieron suponer además un aumento de la población, hecho este documentado por la arqueología gracias a los numerosos conjuntos de enterramientos excavados principalmente en el istmo de Puerta de Tierra, superando los límites de la necrópolis fenicia. El tipo de enterramiento por excelencia es el de inhumación en tumbas de sillería depositadas en una gran fosa. Estas tumbas pueden aparecer aisladas o bien formando conjuntos (Láminas 5, 6 y 7). En el primer caso los ejemplos conocidos son escasos, destacando entre ellas la que contenía el sarcófago sidonio femenino hallado en la actual calle Parlamento en 1980 (Lámina 4). En el segundo caso, los ejemplos son más abundantes. Las tumbas aparecen adosadas unas a otras con un lateral que sirve de muro intermedio para cada dos sepulturas y distribuidas en una o varias filas. Éstas pueden aparecer dispuestas horizontalmente en el suelo o superpuestas en varios pisos. Los ajuares lo forman exclusivamente objetos de adorno personal (anillos, amuletos, pendientes, brazaletes etc.) exponentes de un taller gaditano en el que los orfebres dominaban con maestría las técnicas de la filigrana y el granulado (Muñoz Vicente 1983-84; Perdigones, Muñoz y Pisano 1990). 
A partir de un momento indeterminado del siglo IV a.n.e., las tumbas gaditanas evolucionan hacia tipos más sencillos y de menor complejidad arquitectónica. Continúa el ritual de la inhumación, si bien existen algunos ejemplos del empleo de la incineración, pero en un porcentaje insignificante. Desde aproximadamente finales del siglo III a.n.e. la utilización de sillares se aplica únicamente para las cubiertas de las sepulturas, que adoptan como tipo más común la fosa simple excavada en el subsuelo geológico, a veces con laterales de paramentos de piedras pequeñas o algún que otro sillar escasamente labrado. Estos tipos perduran incluso durante la fase romana republicana y es costumbre acompañar al cadáver con ungüentarios cerámicos, askoi, algún que otro cuenco o platillo de cerámica común y en menor grado joyas de escaso valor, preferentemente anillos realizados a base de una lámina delgada de oro tipo vitola, sin la complejidad artística de los momentos anteriores.

\section{INTERPRETACIÓN HISTÓRICA}

A partir de la segunda mitad del s. VI a.n.e. se producen una serie de circunstancias y avatares históricos que determinarán un período de crisis y desintegración del Modelo Colonial Arcaico para culminar en un proceso de reconversión que generará nuevas formas de organización (Frutos y Muñoz 1996: 133-165; Chic y Frutos 1984: 201-227). Este proceso de cambio ha sido definido como la emergencia o transformación en poleis por algunos autores (Arteaga 1994: 23- 57; Arteaga 2001: 217-219).

Desde estos momentos empezamos a contemplar un modo de organización político-económico de interdependencia entre estas ciudades -que, por lo demás, se originaron a partir de esa política colonial organizada desde Gadir en la etapa anterior- pero con clara tendencia a la centralización en torno a Gadir, que no hacen sino recordar un fenómeno similar a la época arcaica: esto es lo que se podría deducir de las producciones características de esta época como las ánforas o, posteriormente las llamadas cerámicas de kuass y las acuñaciones de monedas. Otros indicios, como las actividades productivas en torno a los recursos derivados de la pesca, que ahora toman un carácter industrial, parecen apuntar hacia estas nuevas directrices. En efecto, las fuentes escritas solo se refieren a Gadir y a los gaditanos como artífices de tales producciones, no haciéndose mención alguna a otros centros de producción hasta épocas posteriores al final de la segunda guerra púnica, a pesar de que los registros arqueológicos nos indican que estas se realizaban en momentos anteriores en lugares como El Majuelo o, recientemente, en Tavira (Frutos y Muñoz 2003: 249-271).

Otras manifestaciones cívico-políticas nos podrían corroborar esta interpretación: las necrópolis de las diferentes poleis púnicas nos manifiestan unas costumbres funerarias muy similares entre ellas, utilizándose estructuras y ritos comunes, aunque con ciertas peculiaridades locales (Ferrer Albelda 1998: 48-49). Sin embargo, hay que destacar un mayor índice de riqueza en los ajuares de las tumbas de la polis gaditana (Perdigones, Muñoz y Pisano 1990), hecho este que se correspondería con la posible concentración de elementos de la oligarquía púnica occidental en la ciudad gaditana ya que, probablemente, desde aquí se dirigirían los destinos de la Circunscripción Púnica Occidental (Frutos y Muñoz 2003: 259). Es, precisamente, a partir de los hallazgos funerarios de donde podemos también contemplar la prosperidad resultante de este nuevo orden político-económico: pues nos muestran un paisaje asimétrico bastante acusado observándose agrupaciones de enterramientos en determinadas áreas que parecen responder a unas pautas de división por grupos o linajes que podrían estar en consonancia con la posición privilegiada que ocupaban frente a la mayoría de las tumbas y que nos proyectarían el esquema social en el que se hallaba articulada la organización interna de los habitantes de la polis. Sus ajuares muestran un altísimo poder adquisitivo formado por piezas de oro y objetos de lujo que nos aperciben no sólo de su gran opulencia sino que nos estarían indicando también la amplitud y la variedad de lugares en los que se desarrollaban las relaciones políticas y comerciales de la Circunscripción Púnica Gaditana:

ISSN: 1133-4525 ISSN-e: 2255-3924

SPAL 14 (2005)

http://dx.doi.org/10.12795/spal.2005.i14.05 
producciones egipcias o egiptizantes, de las ciudades griegas de Sicilia y Magna Grecia, Masalia y su área de influencia, del Levante Mediterráneo, de Atenas, Corinto y otras ciudades de la Hélade así como del Círculo Púnico del Mediterráneo Central (Ebussus, ciudades púnicas de Sicilia y Cerdeña y Cartago, principalmente).

En consonancia con lo que acabamos de exponer se encontraría el gran apogeo que cobran las numerosas actividades económicas que conformarían el panorama laboral y productivo de las ciudades púnicas de occidente. Para el caso de Gadir se observaría como reflejo de ello el acusado impulso expansivo en torno a la khora que se plasma en una mayor incidencia ocupacional de esta en unos marcos territoriales ya diseñados en el período anterior. Resultado de ello sería una reordenación del territorio que conllevaría una probable dispersión de la población gaditana en núcleos perfectamente planificados en función de la explotación de los recursos de los entonos rurales y marítimos que conforman dicha khora ciudadana (Arteaga 2001: 217-265). Asistimos desde esta época a la creación de emplazamientos rurales como los del Cerro Naranja (González Rodríguez 1987: 27-43) o los de la Sierra de San Cristóbal destinados a la obtención de productos como el aceite o el vino (Ruiz Mata 1995: 174-178), en los que se practicaría una agricultura extensiva con unas técnicas de cultivo y de obtención de productos, que se conjugarían con un sistema de organización similares a los de los entornos rurales ibicencos o cartagineses. Estos métodos agrícolas se combinarían con otros de carácter intensivo practicados en la periferia inmediata de la polis gaditana, tanto en los aledaños del núcleo urbano como en las parcelas marginales y divisorias del recinto funerario o en el extremo de la isla mayor. En estos casos cabría suponer cultivos de huertas y de frutales en los que los fenicios eran consumados especialistas (Saéz Fernández 2001: 91-110).

La explotación de los recursos derivados de la pesca cobra ahora una destacada importancia constituyéndose en una actividad especializada que generó a la ciudad importantes riquezas y una gran fama a nivel internacional, pues estos productos gozaron de una extraordinaria demanda en los principales circuitos comerciales mediterráneos de estos momentos (Frutos y Muñoz 1994: 393-414; Frutos y Muñoz 1996: 133-165). La especial consideración y aprecio de estos productos originó desde mediados del s. VI a.n.e. unas señas de identidad que lo caracterizaban y que eran entendidas en el intrincado y variado mundo de los mercados mediterráneos: se diseñó así una cultura de las conservas de pescado gaditanas sobre unos exponentes de formas y modos en su elaboración, es decir, una gama variada de productos en base a la utilización de diferentes materias primas -variedad de peces y moluscos en diferentes combinaciones y cantidades- como de su identificación externa: mediante la creación de unos recipientes genuinos que actuaron por sí mismos como definidores de denominación de origen (ánforas destinadas exclusivamente a contener estos productos), así como la creación de unas marcas o distintivos cívicos que garantizaran la calidad y la autenticidad de estas producciones.

Todo esto que acabamos de definir traería consigo un esquema de producción bastante complejo que exigiría la intervención de diversos sectores productivos: pesquero, salinero, alfarero, artesano de la elaboración y manipulación de los productos, transportista, maderero, contable y administrativo, comerciantes, etc.), que requeriría una rígida y organizada planificación de todas ellas desde unas instancias rectoras superiores que serían controladas por esas oligarquías ciudadanas que monopolizarían su difusión comercial por los mercados mediterráneos en función de unos conciertos y acuerdos político-administrativos de carácter internacional, tal y como nos han transmitido algunas referencias escritas antiguas (Polibio, III, 22-24; Ps. Aristóteles Mir., 136). En definitiva, la envergadura que alcanza la elaboración de estos productos harán precisas unas condiciones especiales de carácter estratégico en cuanto se refiere a su ubicación: en lugares cercanos o inmediatos a las fuentes básicas de materia prima que requiere la puesta en marcha de estas células industriales productivas. Por ello se explica la localización de estos en sitios como la parte extrema de la isla mayor, que se correspondería con la actual Isla de León, o en los alrededores del Puerto de 
Santa María, pues el proceso de colmatación había generado un paisaje de marismas muy propicio para la obtención de la sal (Alonso, García y Menanteau e.p.). Su situación era también inmejorable para la comunicación con otros entornos cercanos para procurarse los otros elementos básicos como la arcilla necesaria para poner en marcha las unidades alfareras precisas para la elaboración de los contenedores. En fin, se encontraban perfectamente comunicados con los centros primarios (Gadir, Castillo de Doña Blanca) que coordinaban las distintas fases de las que constaba el proceso de abastecimiento, elaboración y expedición de los productos (García Vargas 2001: 9-66; García Vargas y Ferrer Albelda 2001).

Otro aspecto que parece cobrar importancia desde mediados del s. VI a.n.e. es el que atañe a la vinculación de la Circunscripción Púnica Gaditana con el Círculo Púnico del Mediterráneo Central. Es esta una cuestión, como otras muchas relativas a esta etapa, que ha provocado bastantes contrastes de pareceres en función de valorar la "intensidad" y las modalidades o formas de estas relaciones (G. Wagner 1994: 7- 24; López Castro 1991: 87-107; Ferrer Albelda 2000; Frutos 1991). Nosotros pensamos al respecto, que a tenor de las evidencias arqueológicas y escritas el citado proceso de reordenación político-administrativo origina un nuevo panorama en el que el sistema de relaciones del Mediterráneo se vertebra y concentra en torno al núcleo centro mediterráneo en base a unas realidades constituidas por entidades políticas diversas en clara competencia y rivalidad por controlar los circuitos comerciales y ostentar con ello la primacía en el concierto político mediterráneo. Dentro de este horizonte constituido en función de continuos juegos de pactos y alianzas, la Circunscripción Púnica Gaditana se inserta en un mecanismo de relaciones con el Círculo Púnico del Mediterráneo Central que va evolucionando hacia una hegemonía cada vez más acusada de éste sobre aquella hasta desembocar en una situación de control directo en el s. III a.n.e. con la ocupación Bárcida (Frutos y Muñoz 2003: 249-271). Resultado de ello es la introducción de elementos centro-mediterráneos en las manifestaciones materiales de Gadir que podrían reflejar notorios cambios en las esferas sociales, políticas y económicas de la polis. Desde fines del s. VI a.n.e. en la necrópolis gaditana empiezan a observarse cambios significativos en las estructuras de los enterramientos así como en sus ritos (paso de la incineración a la inhumación en tumbas de morfologías diversas con ajuares funerarios que acumulan notorias innovaciones en su composición) que revelan bastantes similitudes y afinidades con el mundo funerario ibicenco y cartaginés principalmente (Perdigones, Muñoz y Pisano 1990).

En la vertiente religiosa se observa, asimismo, un destacado auge del culto a Tanit y Baal Hammón, que se refleja en el caso de este último en la riqueza y esplendor de los materiales y de las estructuras que se han exhumado en las recientes excavaciones de la Casa del Obispo correspondientes a estas fechas, así como en la calidad de las ofrendas que se han rescatado en los alrededores de la Punta del Nao. Por lo demás, el estudio de piezas diversas encontradas en Gadir nos hablan de la existencia de talleres de terracota que desde el s. VI a.n.e. producen una variada e interesante gama de representaciones que se relacionan con la diosa Tanit en sus diferentes modalidades de ritos y cultos (Ferrer Albelda1995-96: 63-76). Desde la vertiente económica se pueden llegar a conclusiones similares en actividades como la agricultura, tanto en lo que se refiere a las técnicas de cultivo como a las de la obtención de productos, como es el caso del vino y del aceite: observándose en ello sistemas de organización y elaboración de la producción idénticos a los encontrados en los asentamientos rurales de Ibiza y Cartago como se ha puesto de relieve en estudios recientes (García Vargas1997; Saéz Fernández 2001: 99-110).

En cuanto a la industria de conservas de pescado, si bien los procesos de organización y elaboración de la producción son gaditanos, sin embargo la expedición de los productos al exterior se encuentran mediatizados al marco de condiciones contenidas en los acuerdos internacionales que contemplan su comercialización en los puertos de comercio ubicados en lugares dentro del núcleo del Círculo Púnico del Mediterráneo Central bajo formas y modalidades específicas acordadas entre Cartago y los Estados interesados, con sus respectivos "aliados". 
A estos esquemas parece también apuntar las aportaciones de la numismática, ya que las acuñaciones más antiguas de Gadir, de alrededor del 300 a.n.e., adquieren iconografías y patrones que imitan a los de las monedas del entorno púnico de Sicilia, Cerdeña o de la propia Cartago, lo que nos llevaría a inferir la posibilidad de que la actividad mercantil y comercial estuviera regida según el sistema de valores vigentes en las poleis púnicas del Mediterráneo central, tanto a nivel de pequeños como de grandes negocios, si damos fe a determinadas afirmaciones según las cuales las monedas de cobre o bronce estaban destinadas a usos y actividades de compra-venta de carácter cotidiano (Alfaro Asíns 1998: 117-127).

Esta etapa que podríamos definirla como una Edad de Oro de Gadir vendría a ensombrecerse a partir de un momento que podríamos situar en la segunda mitad del s. IV a.n.e. en el que se detectan síntomas de crisis que originan un retraimiento en las actividades económicas - de las que la industria de salazones es un buen exponente- y que coincide también con una escasez de enterramientos y una pobreza en el contenido de sus ajuares, mostrando un claro descenso de la población de la ciudad y unas condiciones de vida radicalmente opuestas a los siglos anteriores, que quizá fuese debida a los importantes cambios que se están produciendo en el panorama internacional del Mediterráneo que llevaron a la ruptura del equilibrio en el sistema de relaciones entre las diferentes coaliciones de ciudades-estado que componían el concierto político internacional (Chic y Frutos 1984: 209-221; Frutos 1991). Esta situación traería consigo un ambiente de enfrentamientos bélicos cuyo escenario principal sería precisamente el marco en el que se realizaban los intercambios comerciales acordados en los tratados anteriormente mencionados, y llevaría consigo un notable descenso de estos, originando a su vez una proyección hacia los circuitos comerciales atlánticos o de la Iberia mediterránea: es decir, posiblemente durante un corto espacio de tiempo Gadir y las demás poleis púnicas occidentales gozarían de una mayor capacidad de autonomía en cuanto a la gestión de sus destinos políticos y económicos, aunque en un radio de acción comercial más reducido respecto a rutas y mercados.

\section{BIBLIOGRAFÍA}

ALONSO VILLALOBOS, C.; GARCIA PRIETO, J. F. y MENANTEAU, L. (2003): "Las salinas de la Bahía de Cádiz durante la Antigüedad: visión geoarqueológica de un problema histórico", Spal, 12: 317-332. http://dx.doi.org/10.12795/spal.2003.112.13

ALFARO ASINS, C. (1998): "Economía y circulación monetaria en la segunda guerra púnica", La segunda guerra púnica en Ibéria. XIII Jornadas de Arqueología Fenicio-Púnica: 117-127.

ÁlVAREZ, A. y CORZO, R. (1993-94): "Cinco nuevas terracotas gaditanas", Boletín del Museo de Cádiz VI. Cádiz.

ARTEAGA MATUTE, O.: (1994): "La Liga Púnica Gaditana”, Cartago, Gadir, Ebusus y la influencia púnica en los territorios hispanos VIII jornadas de arqueología fenico-púnicas (Ibiza, 1993): 23-57.

(2001): "La emergencia de la polis en el mundo púnico occidental", Protohistoria de la Península Ibérica: $217-281$.

ARTEAGA, O.; KÖLLING, A.; KÖLLING, M.; ROOS, A.M.; SCHULZ, H. y SCHULZ, H.D. (2001): "El Puerto de Gadir. Investigación geoarqueológica en el casco antiguo de Cádiz", Revista Atlántica-Mediterránea de Prehistoria y Arqueología Social 4. Cádiz.

BERNAL,D.; DÍAZ, J.J.; EXPÓSITO, J.A.; SÁEZ, A.M.; LORENZO, L. y SÁEZ, A. (2003): Arqueología y Urbanismo. Avance de los hallazgos de época púnica y romana en las obras de la carretera de Camposoto (San Fernando, Cádiz).

CHIC GARCÍA, G. y FRUTOS REYES, G. DE (1984): "La Península Ibérica en el marco de las colonizaciones mediterráneas", Habis 15: 201-227. Sevilla. 
FERRER ALBELDA, E. (1995-96 ): “Anotaciones al taller cerámico de Gadir”, Boletín del Museo de Cádiz 7. Cádiz.

- (1998): “Suplemento al mapa paletnológico de la Península Ibérica. Los púnicos de Iberia”, Rivista di Studi Fenici XVI, 1: 31-54. Roma.

FRUTOS REYES, G. (1991): Cartago y la política colonial. Los casos norteafricano e hispano. Écija.

FRUTOS, G. DE y MUÑOZ VICENTE, A. (1994): "Hornos púnicos de Torre Alta (San Fernando, Cádiz)", Arqueología en el entorno del Bajo Guadiana. Huelva.

(1996): "La industria pesquera y conservera púnico-gaditana: balance de la investigación. Nuevas perspectivas", Spal 5: 133-165. Sevilla. http://dx.doi.org/10.12795/spal.1996.i5.07

- (2003): "Aportaciones al estudio de Gadir durante los enfrentamientos romano-cartagineses", Actas del III Congreso de Historia de Andalucía 4: 249-271. Córdoba.

GARCÍA VARGAS, E. (2002): "Pesca, sal y salazones en las ciudades fenicio-púnicas del sur de Iberia", De la mar y de la tierra. Producciones y productos fenicio-púnicos XVI jornadas de arqueología fenicia-púnica: 9-66, Ibiza.

— (1997): Producción y comercio de salazones y salsas saladas de pescado de la Bahía de Cádiz en época romana. Tesis Doctoral inédita. Universidad de Sevilla.

GARCÍA VARGAS, E y FERRER ALBELDA, E. (2001): "Las salazones de pescado en la Gadir púnica. Estructuras de producción", Laverna 12: 21-41.

GONZÁLEZ RODRÍGUEZ, R. (1987): "Notas sobre las excavaciones en el yacimiento prerromano de Cerro Naranja (finca de Los Gracilazos 1), Jerez de la Frontera, Cádiz", Cádiz en su Historia. VI Jornadas de Historia de Cádiz: 27-43. Cádiz.

GONZÁLEZ TORAYA, B.; TORRES, J.; LAGÓSTENA, L. y HIGUERAS,A. (2001): “Los inicios de la producción anfórica en la bahía gaditana en época republicana: la intervención de urgencia en la Av. Pery Junquera (San Fernando, Cádiz)”, Congr. Inter. Ex Baetica Amphorae. Sevilla- Écija.

GONZÁLEZ WAGNER, E. (1994): "El auge de Cartago (s. VI-V) y su manifestación en la Península Ibérica", Cartago, Gadir, Ebusus y la influencia púnica en los territorios hispanos VIII jornadas de arqueología fenicio-púnica: 7-24. Ibiza.

GUTIÉRREZ, J.Ma. (2004): “La factoría Puerto 19 (El Puerto de Santa María, Cádiz) y la producción de salazones de Gadir", XVI Encuentros de Historia y Arqueología. San Fernando (Cádiz).

LANCEL, S. (1982): Byrsa II. Rapports préliminaires sur les fouilles 1977-1978: niveaux et vestiges puniques. Ecole francaise de Roma. Palais Farnese.

LÓPEZ CASTRO, J.L. (1991): "El imperialismo cartaginés y las ciudades fenicias de la Península Ibérica entre los siglos VI y III a. C.”, Studi di Egittologia e di Antichitá Puniche 9: 87-107.

MUÑOZ VICENTE, A. (1981): "Una lucerna de dos picos de la necrópolis gaditana”, Boletín del Museo de Cádiz III. Cádiz.

— (1983-84): "Aportaciones al estudio de las tumbas de sillería prerromanas de Cádiz", Boletín del Museo de Cádiz IV. Cádiz.

— (1987): "Las ánforas prerromanas de Cádiz. (Informe preliminar)", Anuario Arqueológico de Andalucía'85. Sevilla.

- (1995-96): "Secuencia histórica del asentamiento fenicio-púnico de Cádiz: un análisis crono-espacial tras quince años de investigación arqueológica", Boletín del Museo de Cádiz VII. Cádiz.

(1998): "Notas sobre la necrópolis fenicia de Cádiz", Homenaje al profesor Carlos Posac Mon. Ceuta

(2002): "El pasado fenicio púnico", Catálogo de la Exposición: Cádiz al fin del milenio: cinco años de arqueología en la ciudad (1995-2000). Cádiz

ISSN: 1133-4525 ISSN-e: 2255-3924

SPAL 14 (2005)

http://dx.doi.org/10.12795/spal.2005.i14.05 
MUÑOZ VICENTE, A. y FRUTOS, G. DE (2004): "El comercio de las salazones en época fenicia púnica en la Bahía de Cádiz. Estado actual de las investigaciones: los registros arqueológicos", XVI Encuentros de Historia y Arqueología. San Fernando (Cádiz).

MUÑOZ VICENTE, A.; FRUTOS, G. DE y BERRIATUA, N. (1988): “Contribución a los orígenes y difusión comercial de la industria pesquera y conservera gaditana a través de las recientes aportaciones de las factorías de salazones de la Bahía de Cádiz", Congr. Inter. El Estrecho de Gibraltar I. Ceuta 1987. Madrid.

NIVEAU DE VILLEDARY, A.Ma . (2001): "Pozos púnicos en la necrópolis de Cádiz: evidencias de prácticas rituales funerarias", Rivista di Studi Fenici. Roma

PERDIGONES MORENO, L.; MUÑOZ VICENTE, A. y PISANO, G. (1990): “La necrópolis fenicio púnica de Cádiz. Siglos VI-IV a.C.”, Studia Púnica 7. Roma.

RAMÓN, J. (1995): "Las ánforas fenicio-púnicas del Mediterráneo Central y Occidental”, Instrumenta 2. Barcelona.

RUIZ GIL, J.A. (1987): "Sondeos arqueológicos de urgencia para la delimitación de las factorías de salazones púnico-gaditanas de El Puerto de Santa María (Cádiz)”,Anuario Arqueológico de Andalucía/1986. Tomo III. Sevilla.

RUIZ MATA, D. (1995): "El vino en época prerromana en Andalucía occidental", Arqueología del vino. Los orígenes del vino en occidente: 174-187. Jerez de la Frontera.

RUIZ, D. y PÉREZ, C. (1995): El poblado fenicio del Castillo de Doña Blanca. El Puerto de Santa María.

SAÉZ FERNÁNDEZ, P. (2001): "Algunas consideraciones sobre la agricultura cartaginesa", De la mar $y$ de la tierra. Producciones y productos fenicio-púnicos. XV Jornadas de Arqueología fenicio-púnica: 91-110. Ibiza.

WILLIAMS II, CH K. (1979): “Corinth 1978: Forum Southwest”, Hesperia 48,2. 


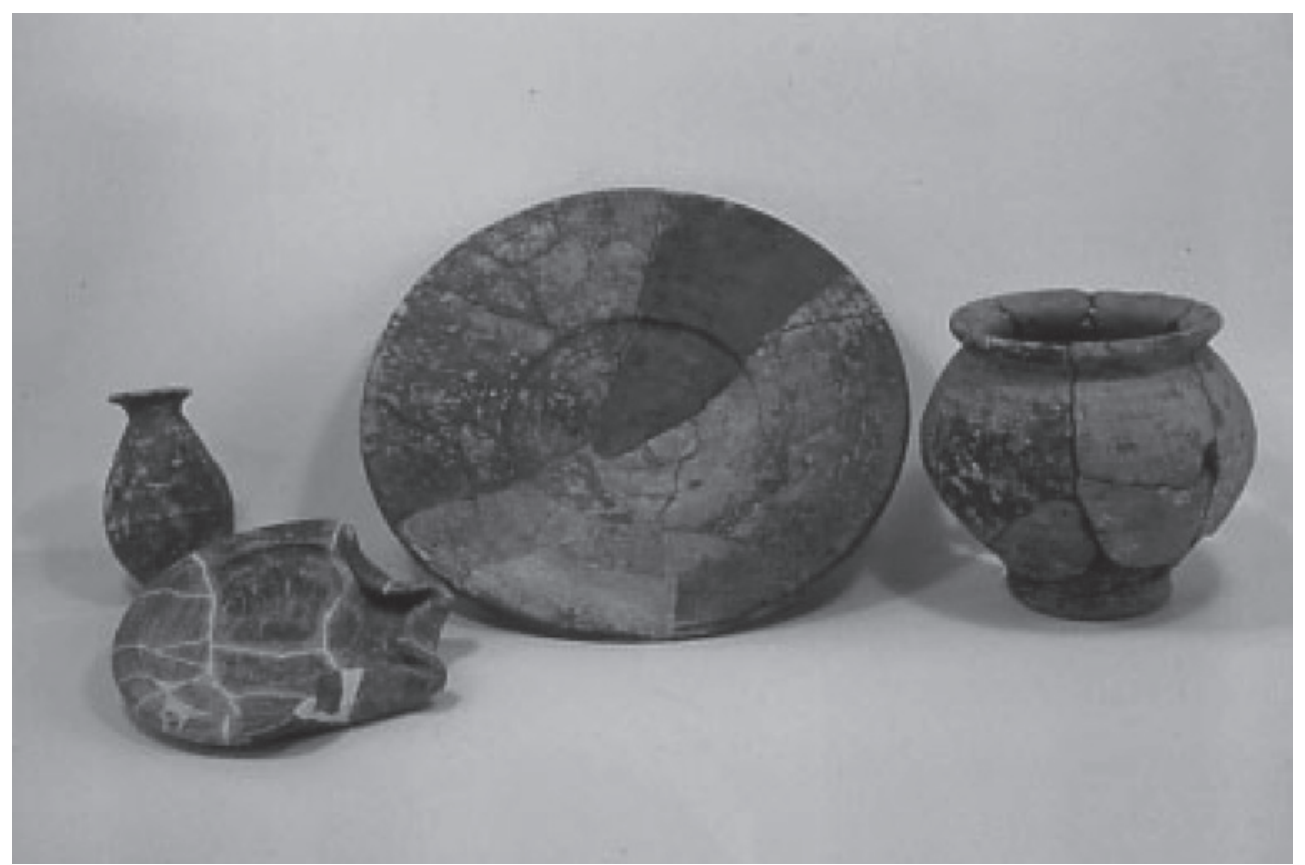

Lámina 1. Ajuares cerámicos de enterramientos del siglo VI a.n.e.

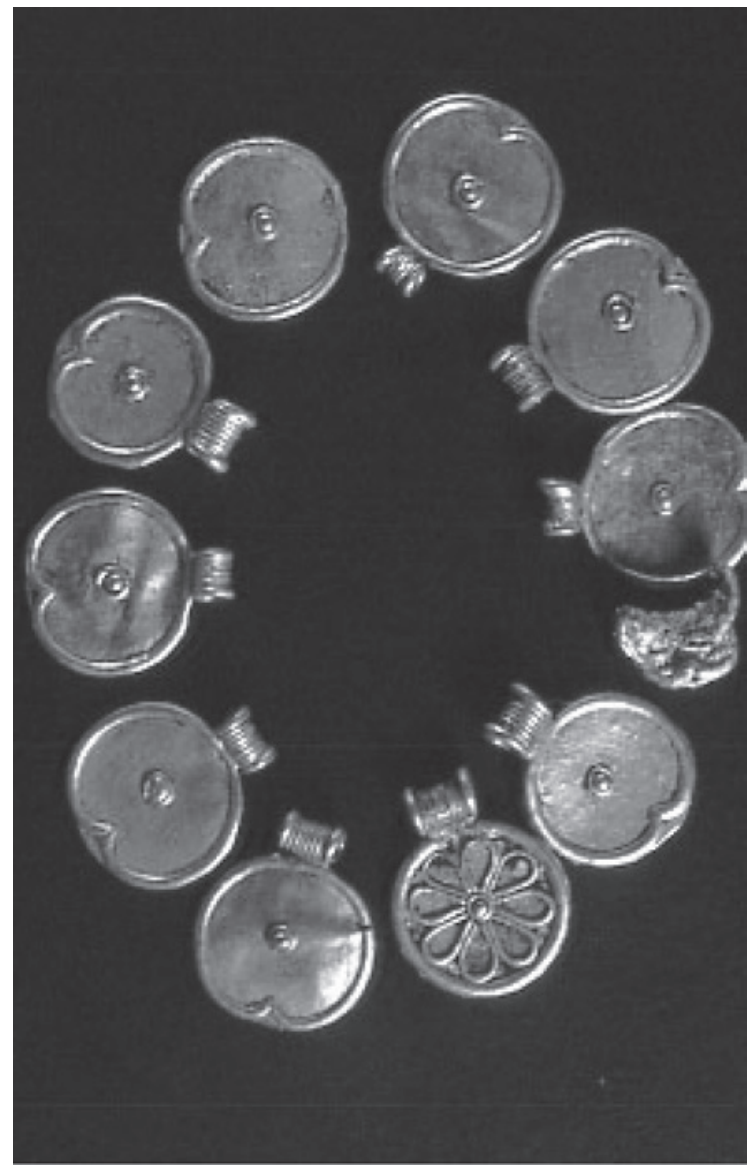
enterramientos del siglo VI a.n.e Cádiz 


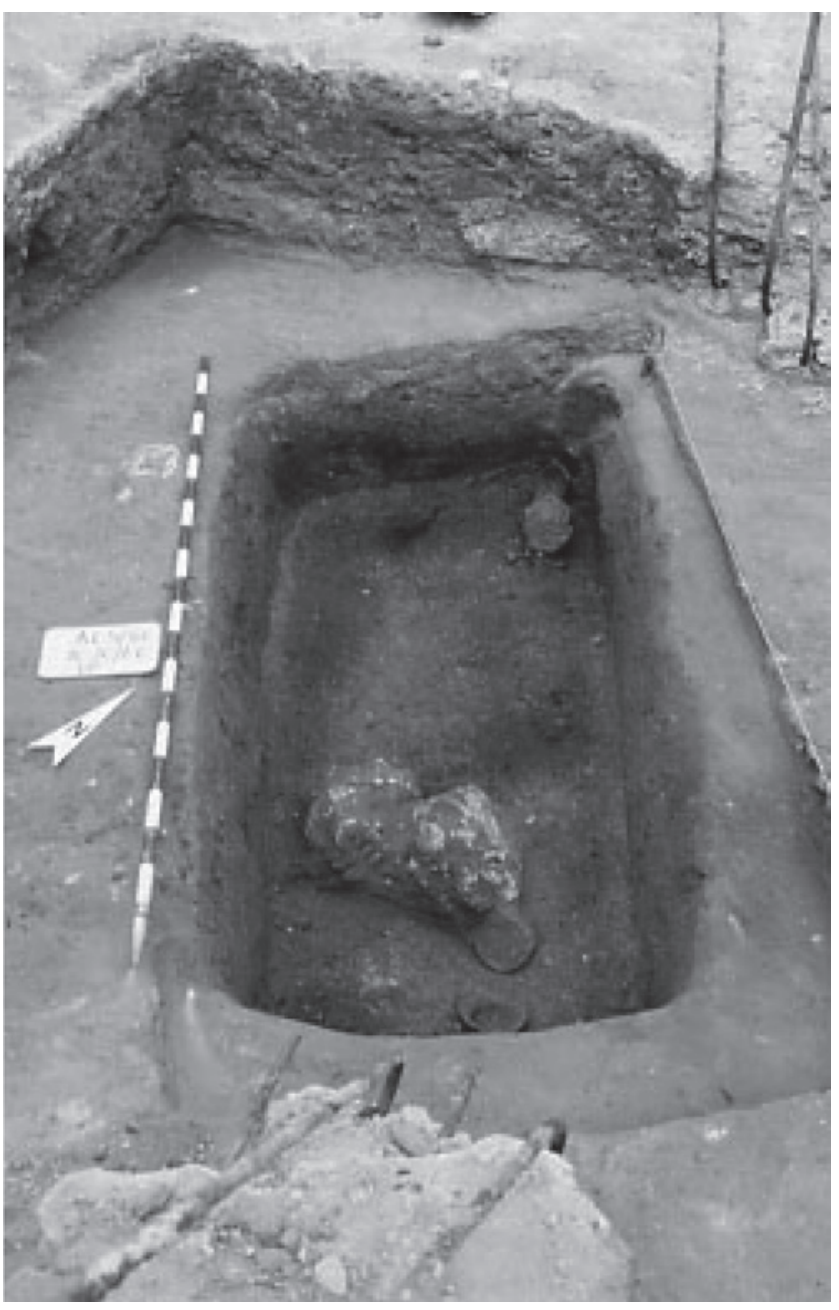

Lámina 3. Tumba de incineración del siglo VI a.n.e. C/Ciudad de Santander e/a Av. Andalucía. Cádiz

Lámina 4. Sarcófagos sidonios localizados en Cádiz

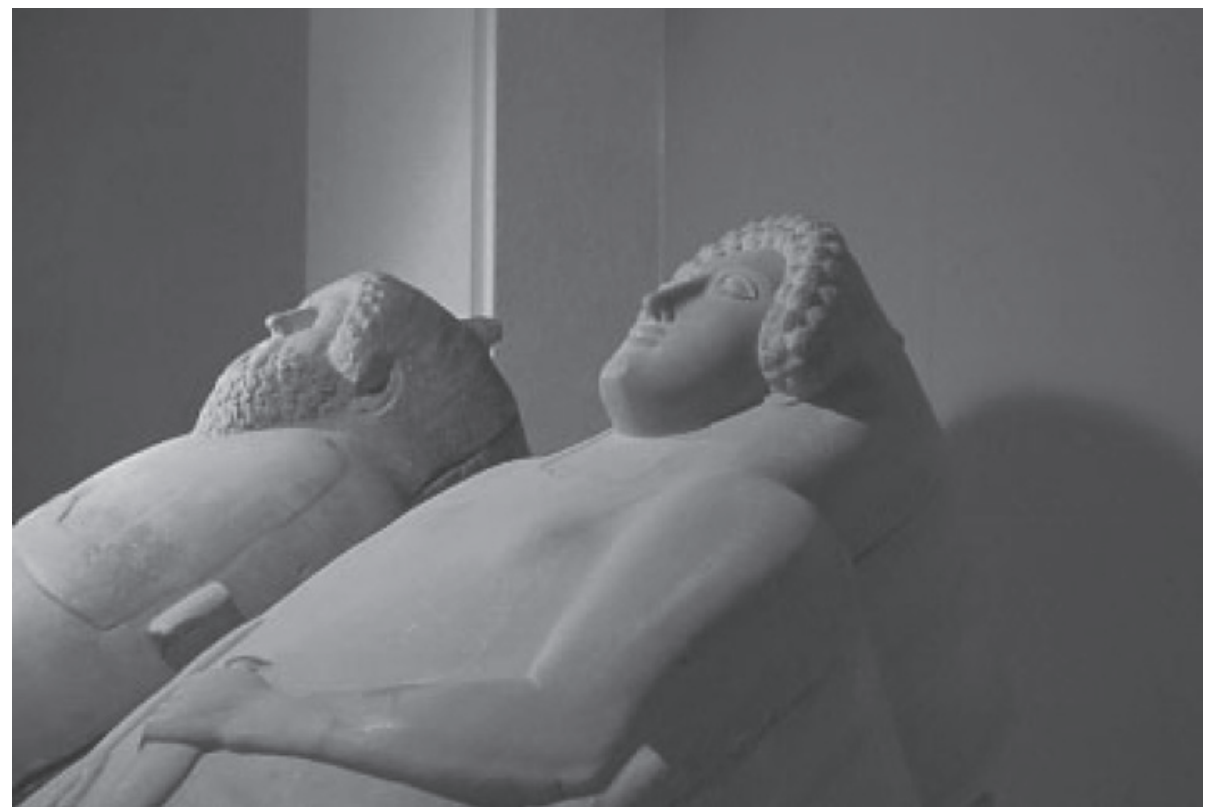

ISSN: 1133-4525 ISSN-e: 2255-3924 http://dx.doi.org/10.12795/spal.2005.i14.05 


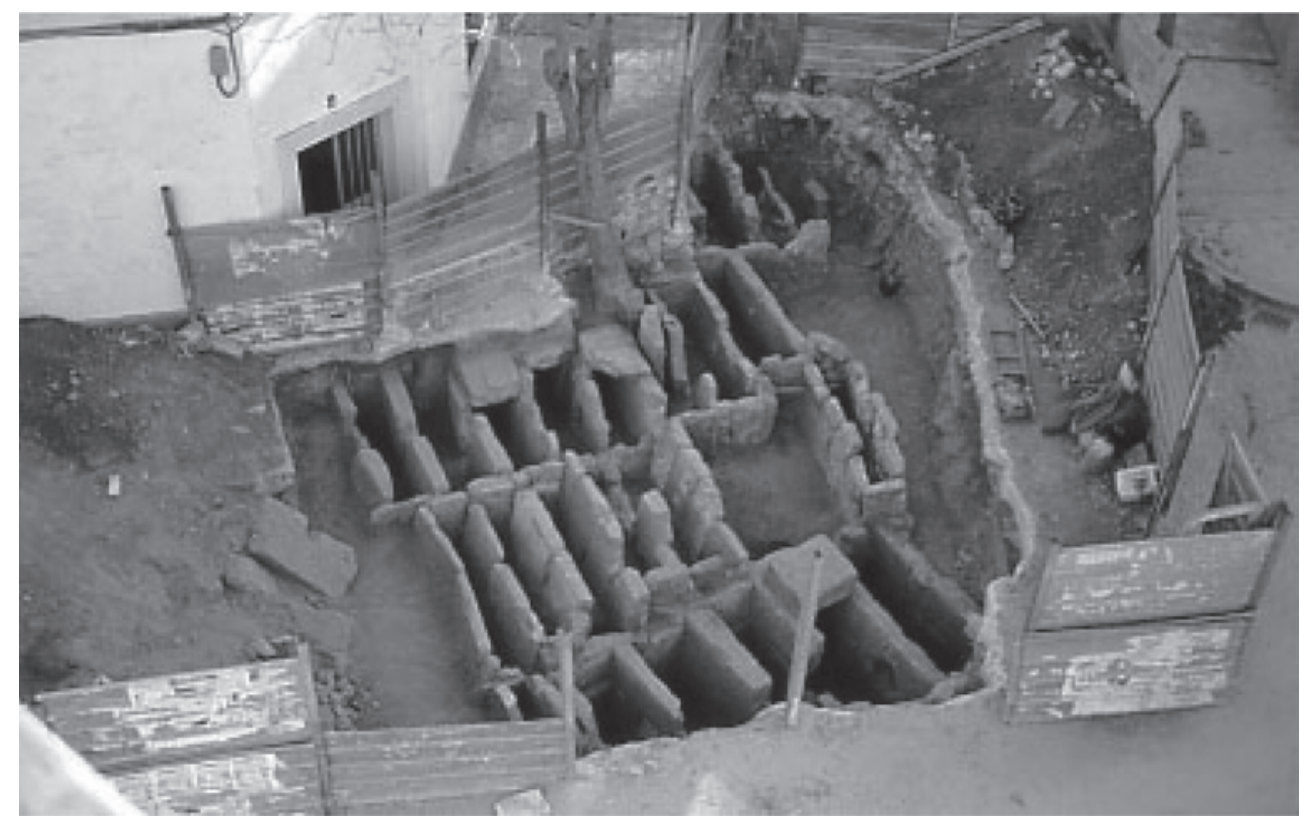

Lámina 5.- Conjunto de tumbas de sillería en fosa de los siglo V-IV a.n.e. C/ Bellavista. Cádiz
Lámina 6. Tumbas de sillería en fosa de la calle Tolosa Latour. Cádiz. Siglo V a.n.e.

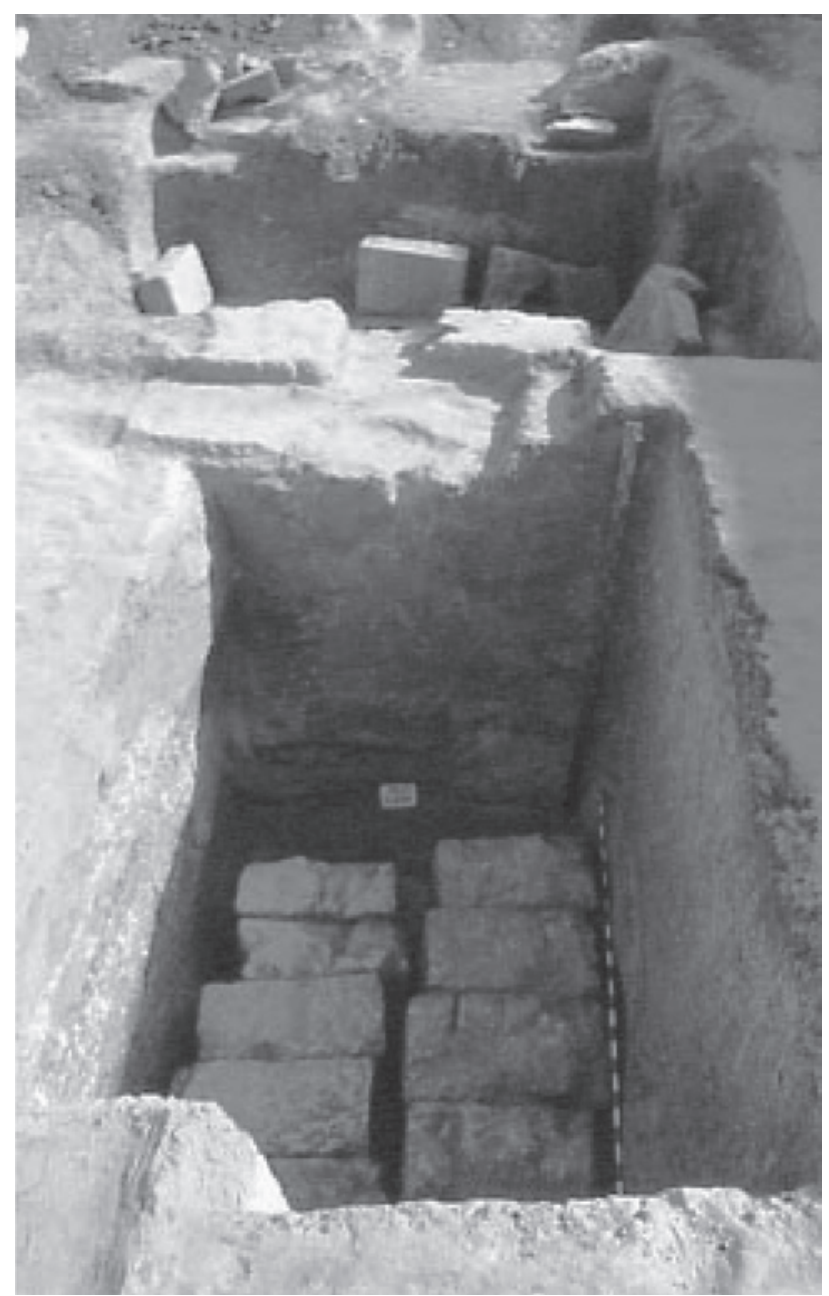

SPAL 14 (2005)

ISSN: 1133-4525 ISSN-e: 2255-3924

http://dx.doi.org/10.12795/spal.2005.114.05 


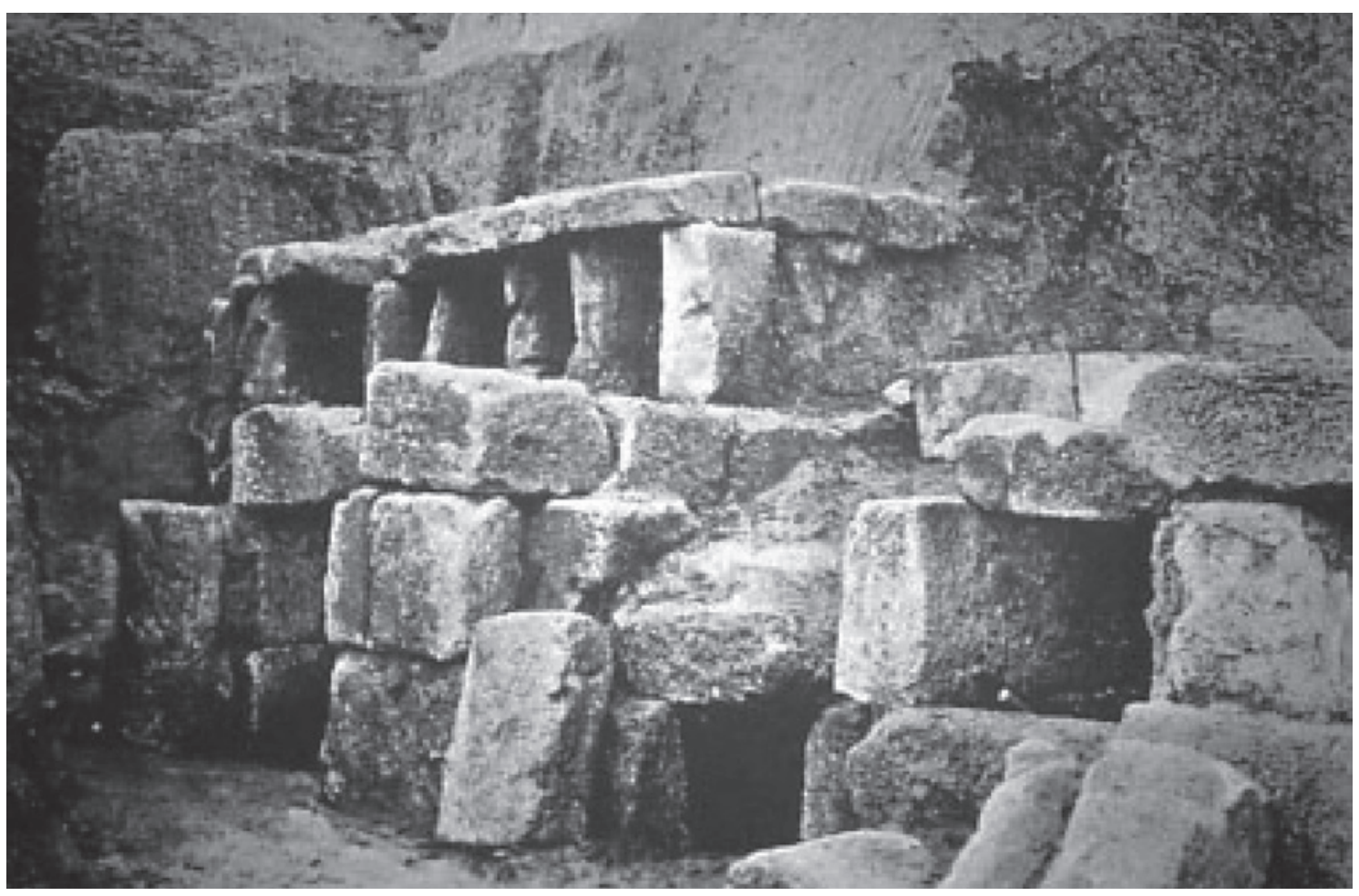

Lámina 7. Tumbas de sillería localizadas en la zona de Astilleros a principios del siglo XX. Cádiz.

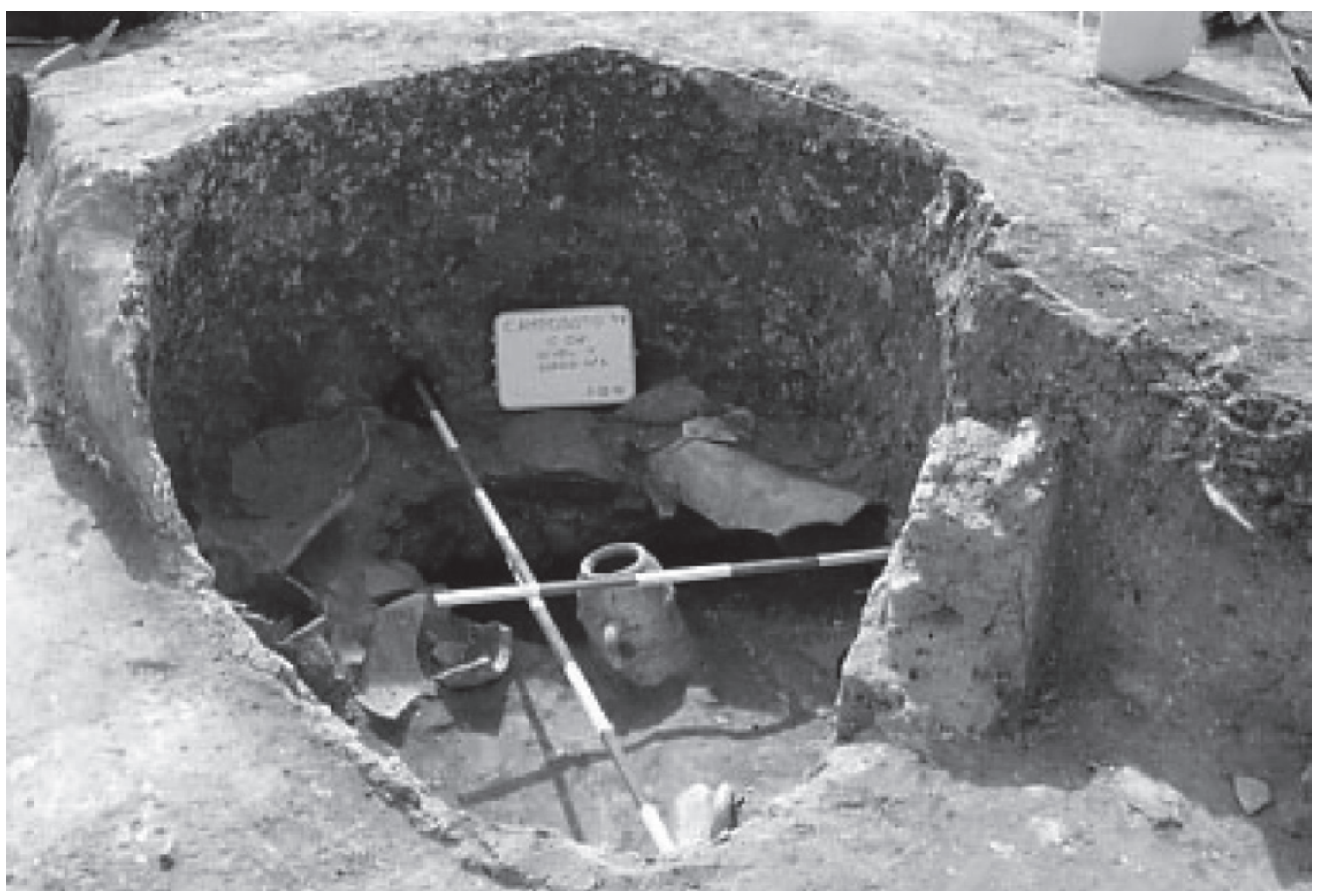

Lámina 8. Cámara de cocción de un horno del sector 3 de Camposoto. San Fernando 


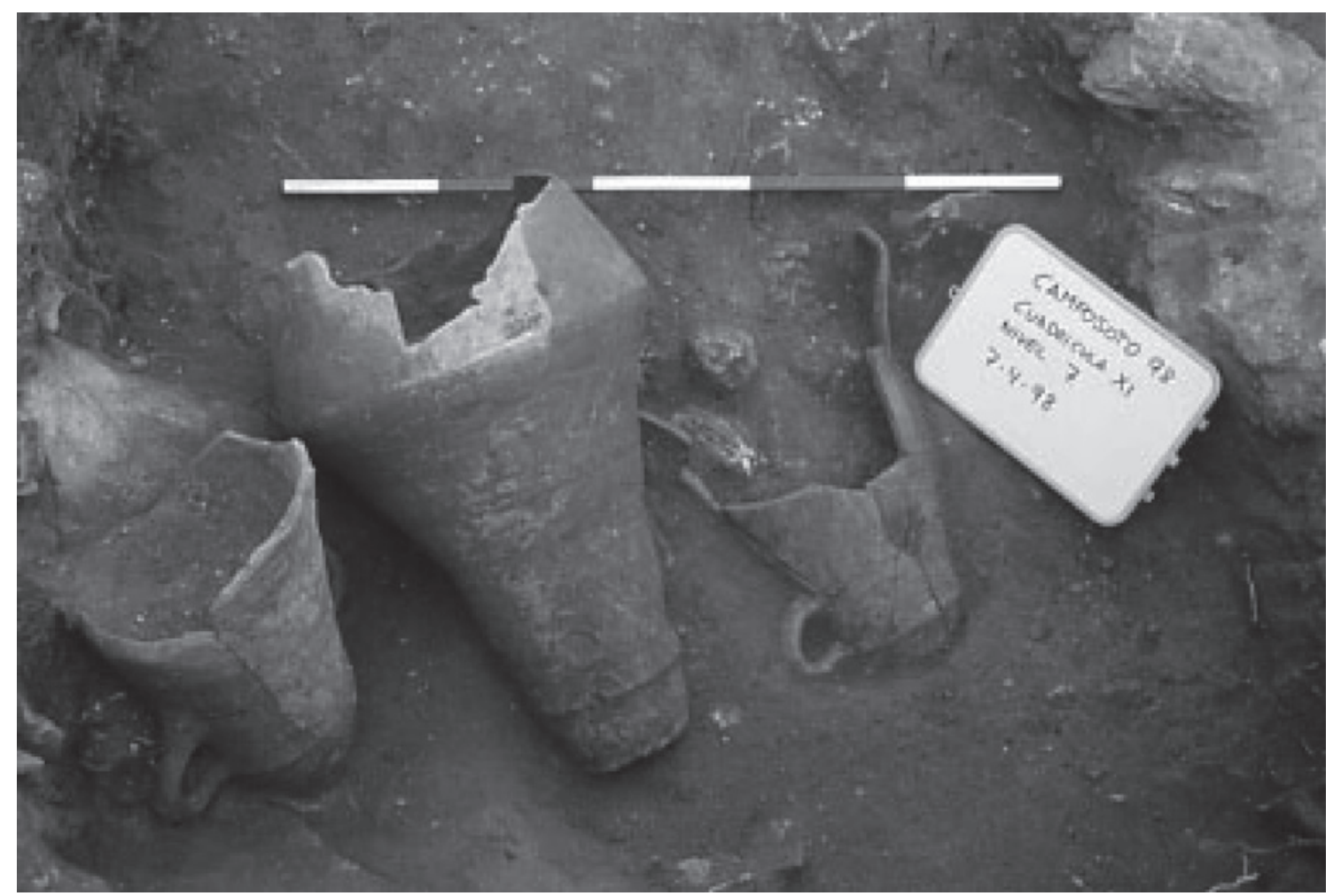

Lámina 9. Ánforas de la fosa entre hornos del sector 3 de Camposoto. San Fernando.

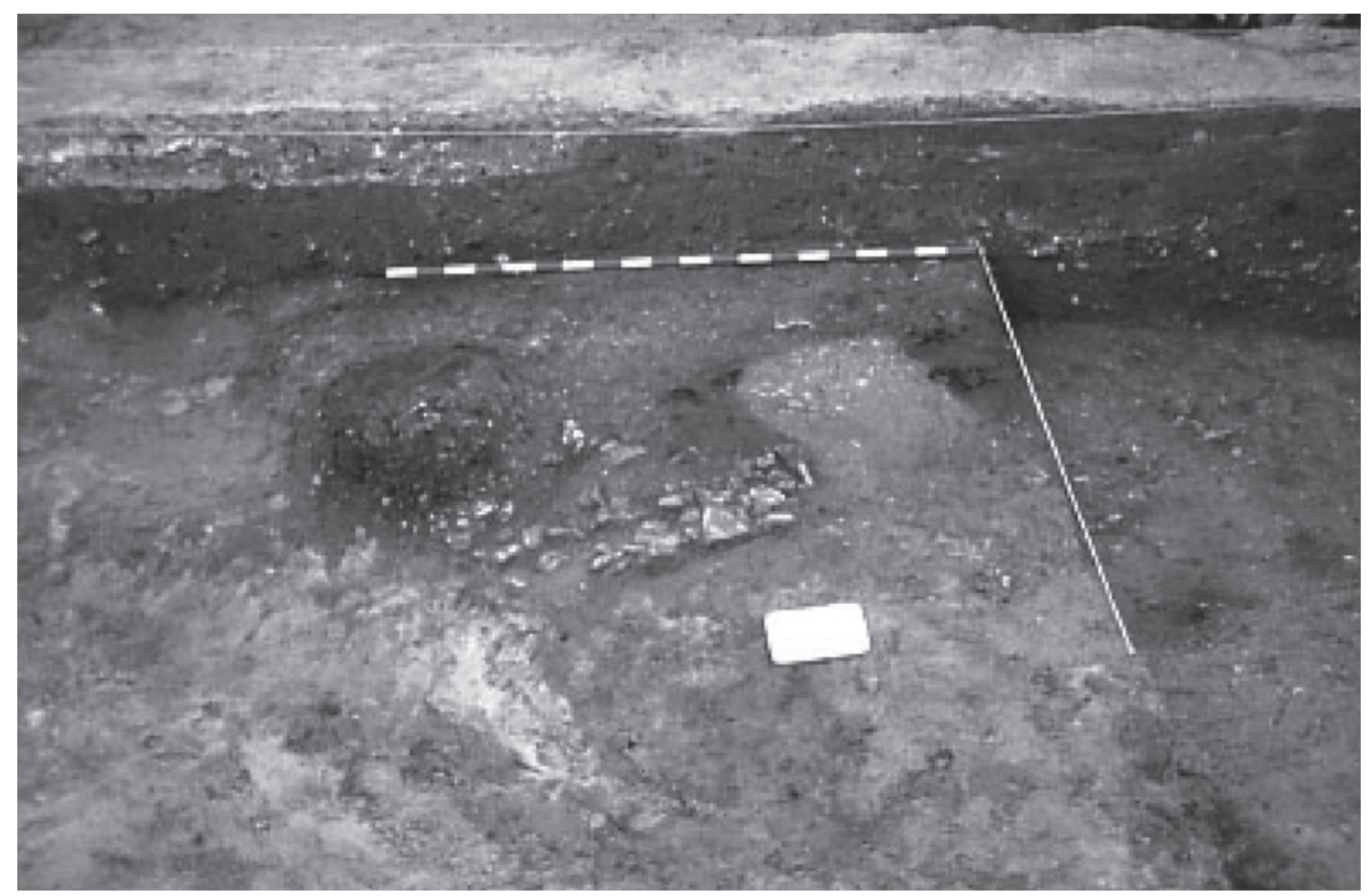

Lámina 10. Estructuras de combustión de la factoría de salazones de la plaza de Asdrúbal. Cádiz

ISSN: 1133-4525 ISSN-e: 2255-3924

http://dx.doi.org/10.12795/spal.2005.i14.05 

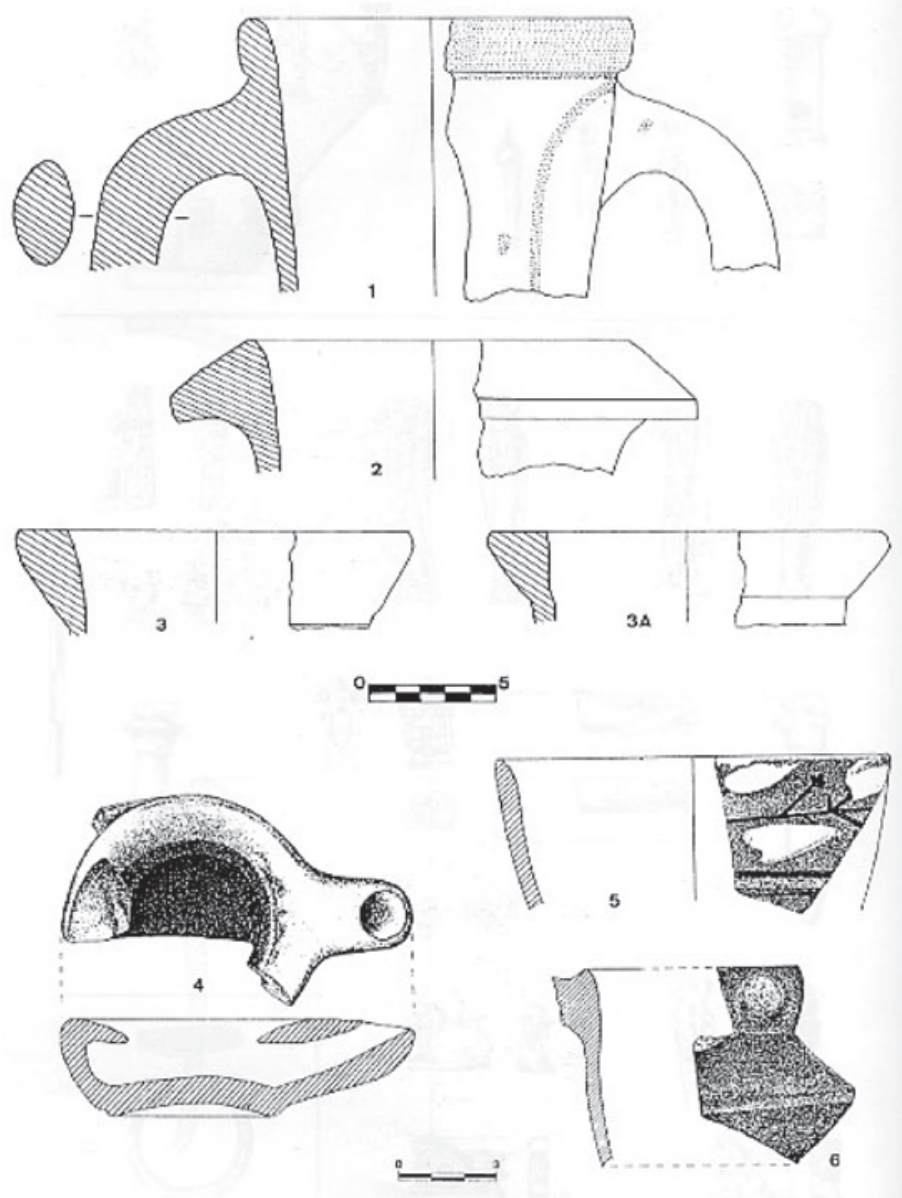

Lámina 12. Ánfora del sector de factorías de salazones de la ciudad de Cádiz.
Lámina 11. Cerámicas griegas de la factoría de salazones de la plaza de Asdrúbal. Cádiz

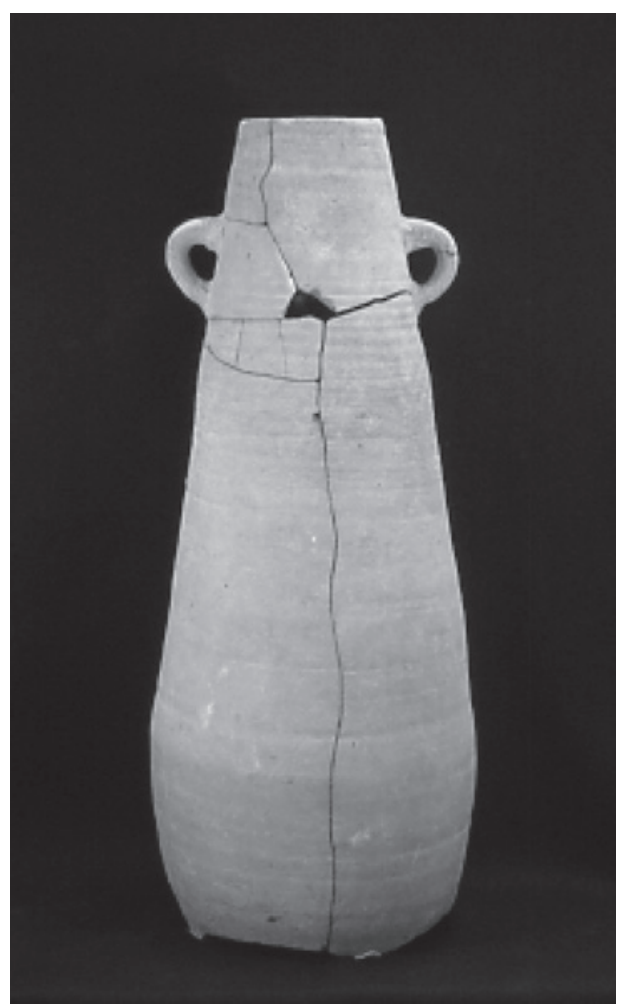

ISSN: 1133-4525 ISSN-e: 2255-3924 http://dx.doi.org/10.12795/spal.2005.i14.05 
Lámina 13. Sector de cantera del siglo $\mathrm{V}$ a.n.e. de la plaza de San Antonio. Cádiz.
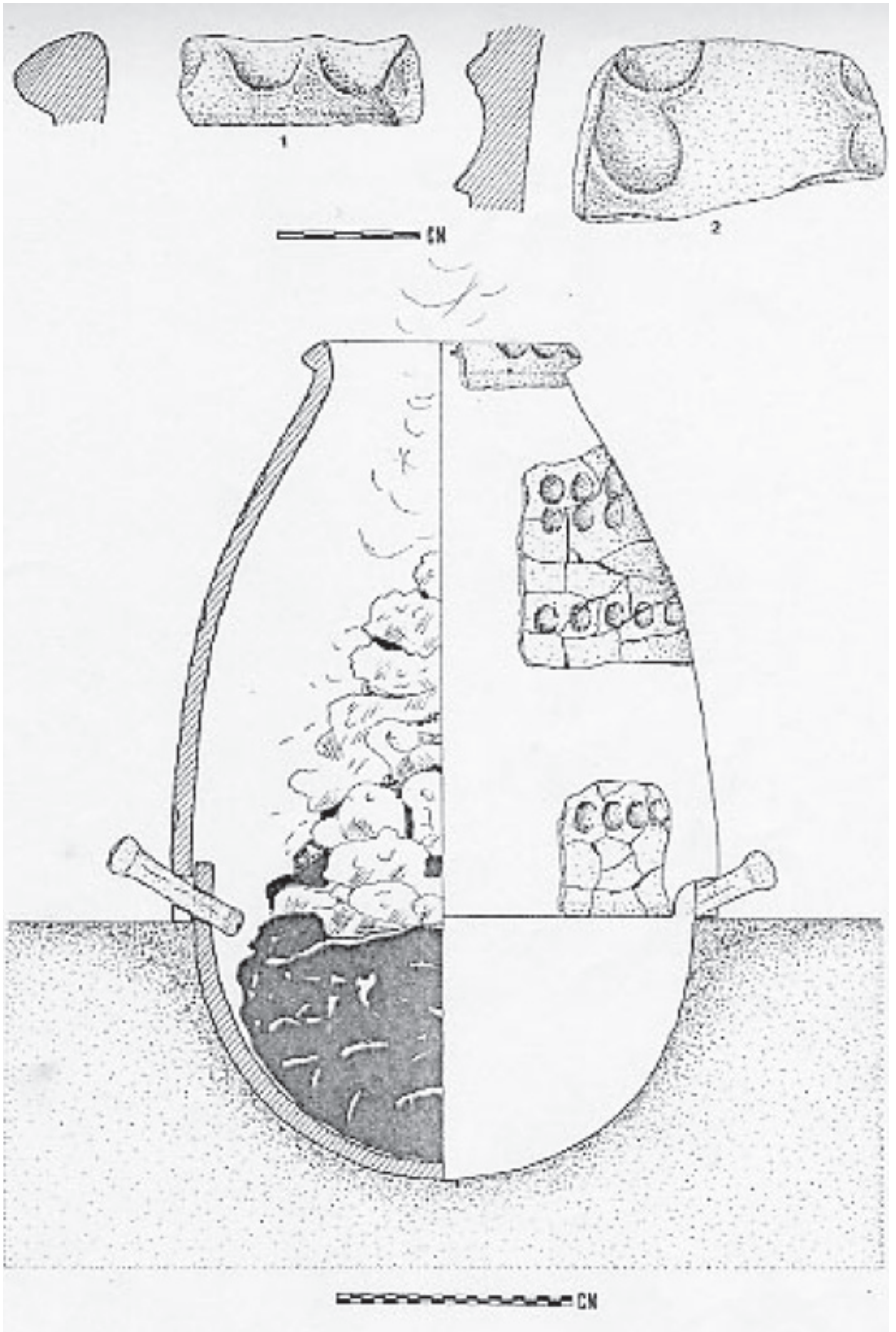

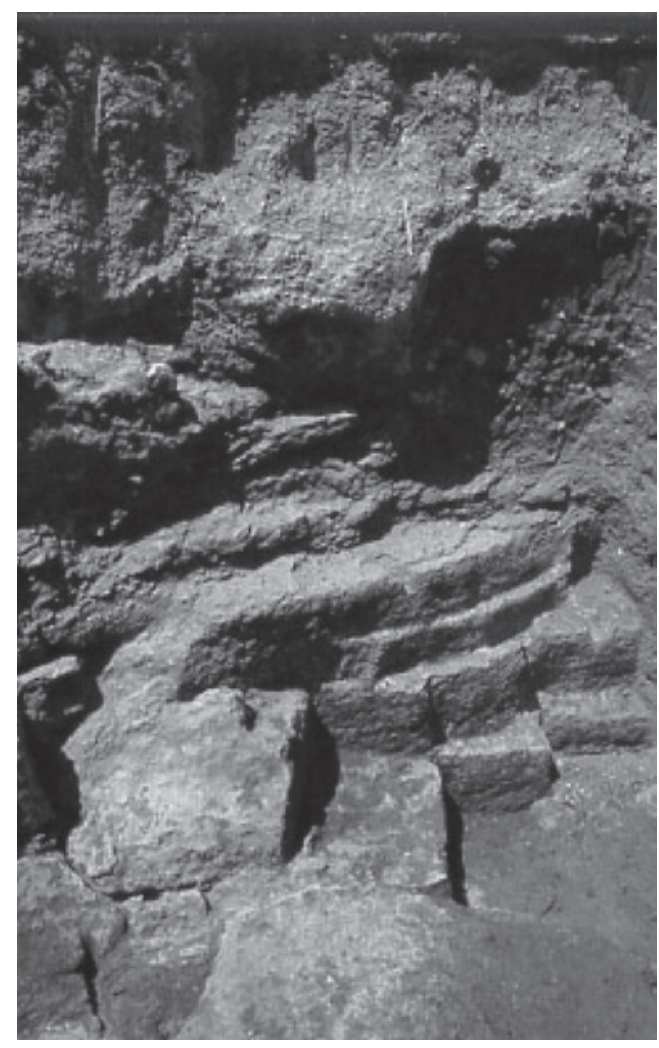

Lámina 14. Horno de la playa Santa María del Mar. Cádiz. 


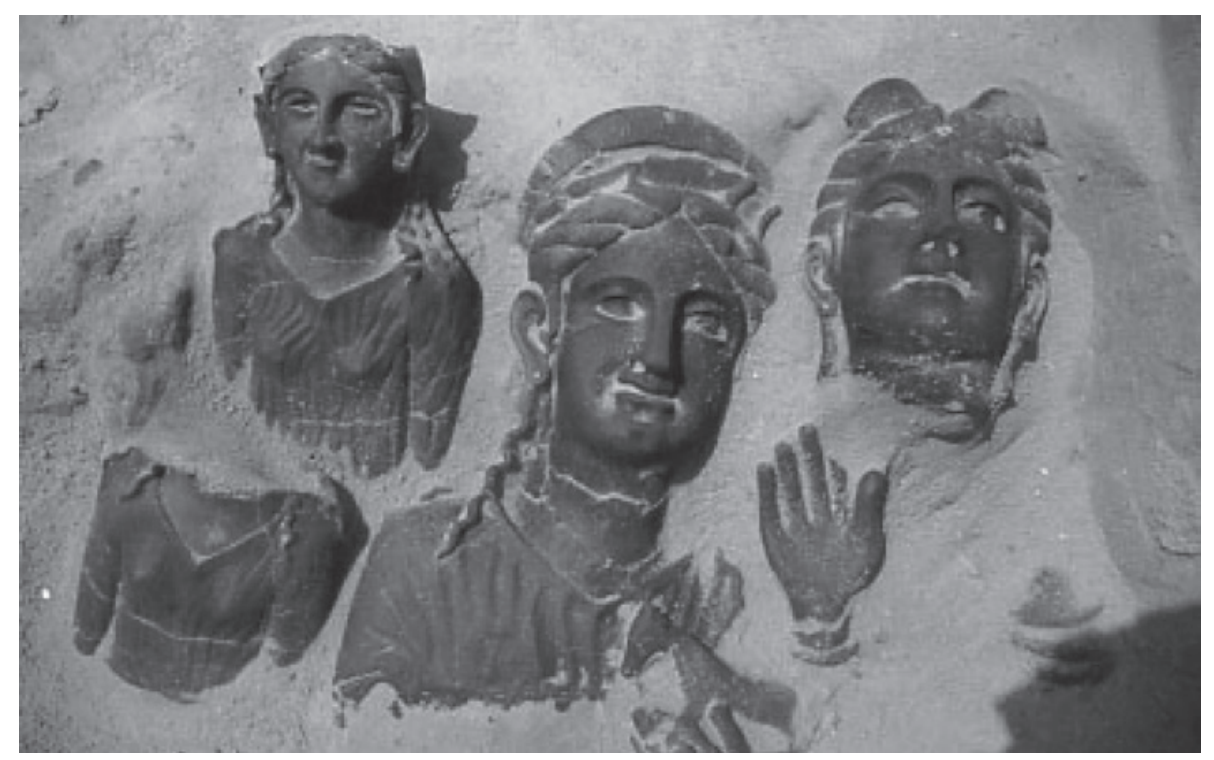

Lámina 15. Conjunto de terracotas del vertedero del solar de la calle Juan Ramón Jiménez de Cádiz

Lámina 16. Propuesta de reconstrucción del poblamiento gaditano durante el periodo fenicio- púnico en base a los sondeos geoarqueológicos realizados por el Proyecto Antípolis (Arteaga et alii, 2001).

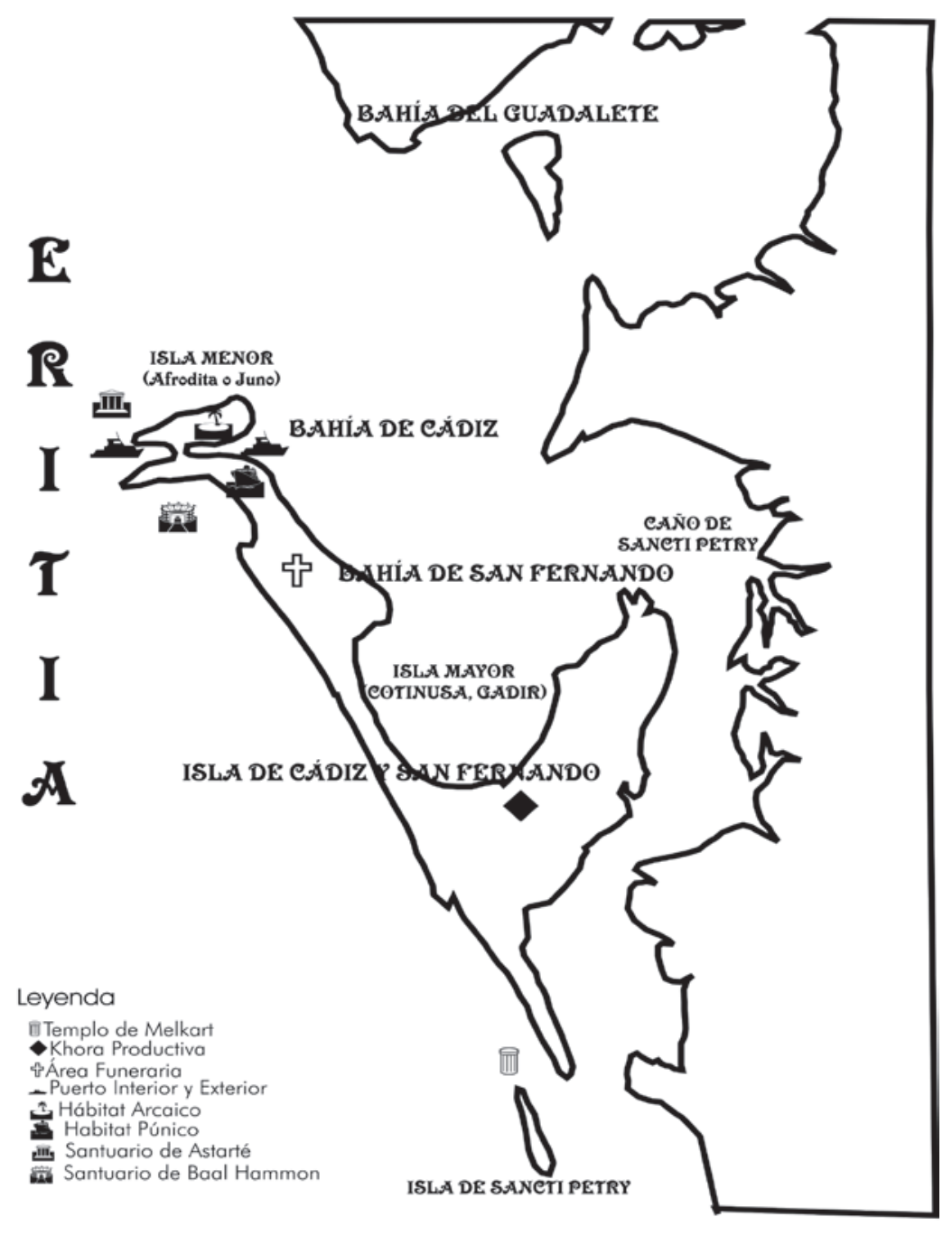

ISSN: 1133-4525 ISSN-e: 2255-3924 http://dx.doi.org/10.12795/spal.2005.i14.05 